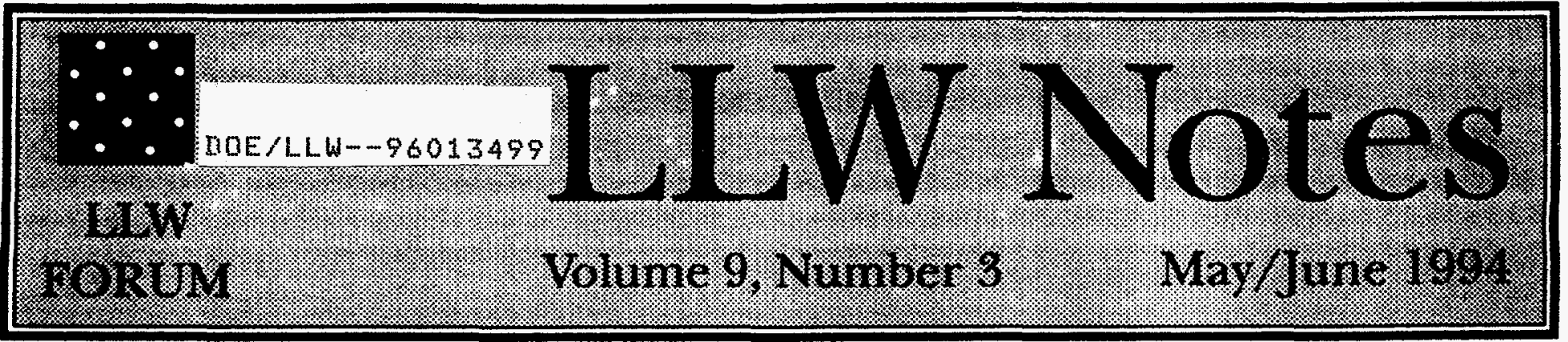

\title{
Texas Compact/Texas
}

\section{Vermont Ratifies Texas Compact}

Legislation to allow the state of Vermont to join the Texas Low-Level Radioactive Waste Disposal Compact was signed into law on April 21. The legislation had previously passed both the state house of representatives and senate by a respectable margin. In a prepared statement, Vermont Governor Howard Dean commented that the compact agreement "is a giant step toward solving for Vermont an issue that is one of the most vexing in the nation."

The compact had previously been signed into law by the Governors of Texas and Maine in June 1993 and approved in a required statewide referendu $m$ in Maine in November of that year. (See LLWNotes, Winter 1993, p. 13.) The Governors and state legislatures of all three compact party states were congratulated in a letter sent by the LLW Forum on May 4, 1994 (see related story, this issue).

\section{The Compact Agreement}

Under the terms of the compact, Texas will host a lowlevel radioactive waste disposal facility. Maine and Vermont are named as the other party states, although additional states may be admitted under terms and conditions set by the host state, "subject to fulfillment of the rights of the initial nonhost party states."

- Each nonhost party state is required to make a one-time contribution of $\$ 25$ million to Texas, as well as to pay a pro rata share of compact commission expenses and to contribute $\$ 2.5$ million in community assistance funds for the host county.

The amount of waste to be accepted from all nonhost party states is limited to 20 percent of the volume estimated to be disposed of by Texas in the years 19952045 , not to exceed a total of 20,000 cubic feei per year.

\section{Compact Commissioners}

The Texas Low-Level Radioactive Waste Disposal Compact Commission is to be comprised of one voting member from each nonhost party state and six voting members from Texas. The Governors of Maine and Vermont have already designated their states' representatives:

- Maine's Commissioner will be Don Hoxie, former Director of the Division of Health Engineering in the state Department of Human Services, who is now retired after a 30 -ycar career with that agency.

- Commissioner for Vermont will be Diane Conrad, who serves as State Geologist and Director of the Radioactive Waste Management Program in the Vermont Agency of Natural Resources. Conrad is also Director of the department's Office of Financial Management and Human Resources.

Among other powers, the compact commission has the authority to enter into agreements for low-level radioactive waste to be imported into the compact for management or disposal "provided that the agreement receives a majority vote of the commission."

The compact commission is expected to be fully constituted by mid-summer.

\section{Next Steps}

The legislation will be submitted to the Congress of the United States for consent. As a result of the compacting, the low-level radioactive waste authorities in both Vermont and Maine will cease to operate by the end of June 1994. 


\section{LLW Forum}

\section{LLW Nater}

Volume 9, Number $3 \bullet$ June 7, 1994

Editor, Qyathia Norris

Contubuting Witters. Holmes Brown, Qhris Eisenbrey, Todd Loninger, Goithia Norris, Laura Scheele, M, A Shaker

Layout \& Design, M. A Shaker

Materills and Publications, Chmis Eisenbrey

$\boldsymbol{L} \boldsymbol{L}$ Notes is distributed by Afton Associates, Inc. to Low-Level Radioactive Waste Forum Participants and other state and compact officials identified by those Participants to receive $L L W$ Notes.

Determinations on which federal officials receive $L L W N$ Notes are made by Afton Associates based on LLW Forum Executive Committee guidelines in consultation with key federal officials. Specific distribution limits for $L L W$ Notes are established by the Executive Committee.

To assist in further distribution, all documents included in Forum mailings are listed in LLW Notes with information on how to obtain them.

Recipients may reproduce and distribute $L L W$ Notes as they see fit, but articles in $L L W$ Notes must be reproduced in their entirety and with full attribution.

The Low-Level Radioactive Waste Forum is an association of representatives of states and compacts established to facilitate state and compact commission implementation of the Low-Level Radioactive Waste Policy Act of 1980 and the LowLevel Radioactive Waste Policy Amendments Act of 1985 and to promote the objectives of low-level radioactive waste regional compacts. The Forum provides an opportunity for states and compacts to share information with one another and to exchange views with officials of federal agencies.

Low-Level Radioactive Waste Forum c/o Afton Associates, Inc. 403 East Capitol Street Washington, DC 20003 (202) 547-2620 • FAX (202) 547-1668

\section{Contents}

Vermont Ratifies Texas Compact ............................. 1

LLW Forum ...................................................... 2

LLW Forum Meeting, April 25-27, 1994 .................... 3

Pennsylvania Study on Rates of Decay for Classes of

Low-Level Radioactive Waste ............................... 8

States and Compacts ........................................... 10

Stohr Named Executive Director of Northwest

Compact .................................................. 10

South Carolina Legislature Adjourns without

Extending Access to Barnwell for Out-of-Region

Generators

Southeast Compact Commission Authorizes

Payments for Facility Development, Also Votes on

Petitions, Access Contracts ................................. 11

Storage of Low-Level Radioactive Waste at

Rancho Seco Removed from Consideration ............ 12

Special Feature: Plutonium Estimates for Ward Valley . 14

Plutonium Estimates for Ward Valley, Califomia .......... 14

Courts ............................................................. 16

Judgment Issued in Ward Valley Lawsuits ................... 16

Other News ......................................................... 18

Host State Technical Coordinating Committee Meets .. 18

Courts continued ................................................ 19

Central Midwest Commission Questions Court's Jurisdiction Over Surcharge Rebates Litigation......... 19

Supreme Court Decides Commerce Clause Case

Involving Solid Waste ..................................... 20

Parties Voluntarily Dismiss Envirocare Case ................ 23

Appellate Court Affirms Dismissal of Suit Against

Central Commission ........................................ 24

LLW Forum continued ........................................ 25

LLW Forum Mixed Waste Working Group Meets ......... 25

Chart: U.S. EPA Office of Radiation and Indoor Air

Rulemakings ............................................ 26

Low-Level Waste Standard ................................ 26

Radiation Site Cleanup Regulation ........................ 27

Comprehensive Waste Management Rule ................... 27

Federal Agencies and Committees ......................... 28

EPA Issues Draft Radiation Site Cleanup Regulation ... 28

EPA Extends Mixed Waste Enforcement Moratorium ... 30

Lash Named Director, DOE Office of Nuclear Energy .. 31

NRC Denies Petition to Amend Low-Level

Radioactive W'aste Classification Regulations ............ 32

New Materials and Publications ............................. 34

Receiving $L L W$ Notes by Mail ............................... 39

Prepared by Aftom Associates for the LLW Forum under State of Washington Department of Ecology Contract Number C 9400065. 


\section{DISCLAIMER}

This report was prepared as an account of work sponsored by an agency of the United States Government. Neither the United States Government nor any agency thereof, nor any of their employees, makes any warranty, express or implied, or assumes any legal liability or responsibility for the accuracy, completeness, or usefulness of any information, apparatus, product, or process disclosed, or represents that its use would not infringe privately owned rights. Reference herein to any specific commercial product, process, or service by trade name, trademark, manufacturer, or otherwise does not necessarily constitute or imply its endorsement, recommendation, or favoring by the United States Government or any agency thereof. The views and opinions of authors expressed herein do not necessarily state or reflect those of the United States Government or any agency thereof. 



\section{DISCLAIMER}

Portions of this document may be illegible in electronic image products. Images are produced from the best available original document. 



\section{LLW Forum continued}

\section{LLW Forum Meeting, April 25-27, 1994}

The LLW Forum met for two-and-one-half days in New Orleans, Louisiana, from April 25-27, 1994. Forum Participants and Alternates representing twenty-three states and compacts attended the meeting. Also in attendance were thirteen additional state and compact representatives; ten officials from federal agencies including the Department of Energy (DOE), Nuclear Regulatory Commission, Environmental Protection Agency, and the Department of the Army; one Congressional committee staff member; seven special resource people; four DOE contractor staff; and two observers representing a local monitoring committee, one observer representing a generator organization, four observers representing disposal facility operators, one observer representing a nuclear power generator, and one observer from another company.

Highlights of the meeting follow. For further information, see LLW Forum Meeting Report, April 25-27, 1994, prepared by Afton Associates, Inc.

\section{LLW Forum Executive Session}

Participants and Forum Alternate Participants only were present for this short session.

LLW Forum Rules Revision Forum Participants agreed that, in order to allow thorough review and discussion of proposed changes to the LLW' Forum Statement of Principles and other operating rules, the changes would be discussed at the current LLW Forum meeting but that a final vote would not be taken until the July LLW Forum meeting.

Approval of Agenda The April meeting agenda was based on proposed changes to the LLWForum Statement of Principles requested by Forum Participants at the January meeting. In order for the current meeting agenda to reflert Participants' wishes without formal approval of the Statement of Principles, a motion approving the agenda and accompanying attendance rules passed unanimously.

1994 Budget Report The Forum Convenor reported that the management contractor had met the budget projections for the first quarter of 1994.

- The remainder of the LLW' Forum meeting was open to the public.

\section{LLW Forum Business Session}

Revision of $L L W$ Forum Statement of Principles and Other Operating Procedur ; Forum Participants discussed proposed changes in the LLW Forum rules focusing on two basic areas in the Statement of Principles-the designation of Forum Participants, Forum Alternates, and meeting alternates; and the revised LLW Forum meeting attendance policy. Discussion followed, during which a number of changes were suggested. Changes will be incorporated and a new draft document will be circulated to all Forum Participants in advance of the July LLW Forum ineeting.

Distribution of $L L W$ Notes The Forum's management firm reported that, at the request of the Executive Committee-and in response to continuing requests from representatives of industry, antinuclear, environmental and citizen groups, as well as other members of the public-it had been exploring mechanisms for mailing each issue of $L L W$ Notes to members of the public. A new mechanism was sought because the practice of referring such requesters to the appropriate Forum Participant and/or to EG\&G Idaho for copies of LLW Forum materials has not satisfied the requesters' interest in receiving $L L W$ Notes by mail when it is distributed to Forum Participants and other state, compact and federal officials. 
The Forum Convenor reported that DOE's National Low-Level Waste Management Program agreed, at the request of the LLW Forum Executive Committee and as part of the DOE mandate to provide information to the public, to maintain a public information mailing list for $L L W$ Notes consisting of interested individuals who are not state, compact or federal officials. The program agreed to mail each issue of $L L W$ Notes but stipulated that the LLW Forum management contractor would have to cover the cost of reproducing extra copies of the publication.

Following discussion, Forum Participants approved the following policy change, indicating that it should be instituted on a trial basis until the cost of the project could be determined.

Members of the public can also apply to the DOE National Low-Level Waste Management Program at EG\&G Idaho, Inc. to be placed on a mailing list to receive $L L W N$ Notes and Summary Report: Low-Level Radioactive Waste Management Activities in States and Compacts by mail. The LLW Forum will monitor distribution of these documents to the general public to ensure that information is equitably distributed throughout the states and compacts.

Status of Manifest Tracking Working Group Forum Participants agreed to put the LLW Forum's Manifest Tracking Working Group on inactive status, since the uniform manifest rulemaking was nearing completion, so that the rescurces budgeted for the group could be used for other LLW Forum activities. Forum Participants and working group members noted their intention to reactivate the group if necessary.

Interaction with Federal Agencies The Forum Convenor and Executive Committee members reported on the recent Executive Committee briefing of congressional staff (see $L L W$ Notes, April 1994). Forum Participants were also provided information about a briefing of Dan Reicher, DOE Deputy Chief of Staff, by Executive Committee members and other Forum Participants. Committee member reported that they were pleased with the interactive session.
Congratulations on Texas Compact The following motion was unanimously approved by Forum Participants and was subsequently transmitted to the appropriate Governors by the LLW Forum Convenor.

Whereas, the federal Low-Level Radioactive Waste Policy Act of 1986, as amended, provides a process for states to join together to form compacts to manage low-level radioactive waste; and

Whereas, the formation of low-level radioactive waste compacts by states generally reduces the number of potential low-level radioactive waste facilities throughout the nation thereby promoting economic and efficient low-level radioactive waste management; and

Whereas, the states of Maine, Texas and Vermont have taken the necessary legal action to form a low-level radioactive waste compact; now

Therefore, be it resolved that the members of the Low-Level Radioactive Waste Forum congratulate the Governors of the states of Maine, Texas and Vermont upon the formation of a low-level radioactive waste compact.

\section{Congressional Activity}

A View From the House Susan Sheridan, Counsel, Subcommittee on Energy and Power, Committee on Energy and Commerce, United States House of Representatives, reported that she is not aware of any plans to institute hearings in Congress on issues related to low-level radioactive waste disposal and that no legislation on this issue has been introduced during this session. Sheridan noted that members of Congress have spoken most eloquently on this issue by not speaking. The mere fact that there have been no oversight hearings on this issue in years indicates that Congress does not want to encourage any misconceptions that new legislation will be introduced on this topic. 


\section{LLW Forum continued}

Sheridan reviewed recent federal activity concerning the proposed transfer of federal land in Ward Valley to the state of California for use in siting a low-level radioactive waste disposal facility. Sheridan also identified four major themes contained in letters on Ward Valley from Senator J. Bennett Johnston (D-LA) and Representatives Philip Sharp (D-IN) and Richard Lehman (D-CA):

- delay by the federal government will politicize an issue that should be beyond politics,

- any delay or appearance of politicization would be destabilizing to other states and compacts working on site development, as well as to California,

- safety is not maximized by on-site storage, and

- the Department of Interior should reach a decision promptly.

\section{Pennsylvania Study on Rates of Decay for Classes of Low-Level Radioactive Waste}

(See accompanying special meeting report excerpt.)

\section{Interregional Transportation of Waste for processing}

A standard session on the interregional transportation of waste for processing will be added to all future LLW Forum agendas in order to provide Forum Participants with a regular opportunity to discuss developments that have an effect on interregional processing.

\section{Waste Information Working Group}

Since the Manifest Tracking Working Group had been put on inactive status, the LLW Forum approved the following motion.

Whereas the NRC's uniform manifest final rulemaking is nearing completion, and

Whereas there are issues that need to be resolved concerning its implementation,

Be it resolved that

The LLW Forum establish a working group to recommend ways of implementing the uniform manifest.

The new working group will discuss interregional agreements, work on tracking svstems, and deal with other issues associated with implementation of the final uniform manifest rule. Forum Participants and others who will serve on the working group are Virgil Autry of South Carolina, Janice Deshais of the Northeast Compact, William Dornsife of Pennsylvania, Michael Klebe of Illinois, and Kevin McCarthy of Connecticut.

\section{Mixed Waste Working Group Report}

Working group members reported that the Federal Facility Compliance Act (FFCA) task force, a group of 21 states that meets under the auspices of the National Governors' Association (NGA), is scheduled to meet with Department of Energy on May 25 and 26 in Washington, DC. A primary objective of the working group is to present the issue of DOE acceptance of commercial mixed waste to the state representatives on the FFCA task force and to obtain agreement to add the issue to NGA's FFCA discussions. (See related story, this issue.)

The LLW Forum then unanimously passed a motion

that Forum Participants contact their state representatives to the NGA FFCA Task Force and urge their support in adding the issue of DOE acceptance of commercial mixed waste to the FFCA process. 


\section{LLW Forum continued}

Environmental Justice: Impact on Low-Level Radioactive Waste Siting

Environmental Justice: An Overview An official from the state of Washington official provided an overview of environmental justice and a description of activities that the state of Washington has undertaken to address environmental justice issues, noting that environmental justice

- promises equal environmental protection to all people while environmental racism has been defined as the denial of equal environmental protection based upon race,

- works to include minorities and low-income people in the decision-making and leadership roles of environmental policy making, from which they have traditionally been excluded, and

- traditionally includes concerns about facility siting and disproportionate impacts of toxic releases on minority and low-income populations.

The official added that the state of Washington is conducting detailed studies of Indian populations and their lifestyles to help determine their level of risk from historic radioactive releases. One of the core values adopted by the Washington Department of Ecology directs employees iv "account for ethnic, cultural and economic factors in our decision making and policy setting."

Executive Order on Federal Actions to Address Environmental Justice in Minority Populations and Low-Income Populations A representative of the U.S. Environmental Protection Agency noted that the main goal of the executive order is to make environmental justice a primary part of the mission of every federal agency. The basic administrative mechanism created by the executive order is an interagency working group. (See LLW Notes. April 1994, p.12.)
An NRC official reported that the agency will be developing an environmental justice strategy based upon the guidance from the interagency working group. He referenced NRC's development of the site cleanup rule, during which NRC worked to ensure that environmental justice representatives participated in the development process. He stated that the executive order applies only to federal agencies and that traditionally the NRC has not required that Agreement States adopt provisions such as this.

During discussion Forum Participants noted that environmental justice has been addressed in a number of states.

\section{Spring 1994 Forum Meeting- Other Topics}

The meeting also addressed the following topics:

- new developments in states and compacts;

- performance assessment;

- effects of residual contamination standards on lowlevel radioactive waste volumes;

- effects of wetlands regulations on siting;

- DOE's decision on surcharge rebates;

- LLW Forum agenda planning;

- states' need clarification of NRC's disposal site land ownership requirements;

- impact of concentration averaging on disposal volumes and curies;

- a report on the Illinois siting process commissioned by the DOE Low-Level Waste Management Program;

- Host State Technical Coordinating Committee (TCC) liaison report; and

- NRC progress on the uniform manifest rulemaking. 


\section{Special Session-Getting a Handle on Volumes and Curies: Potential Factors in Long-Range Projections}

The special session was in troduced with a discussion of high-volume, low-activity waste. Presentations were made on Northwest Compact guidelines forwaste accepted at Envirocare, a Louisiana NORM facility, and military waste streams.

Other items discussed included the following:

- regulatory changes, agency positions, and policy issues that may affect long-range volume and curie projections, such as DOE's interpretation of the standard contract, concentration averaging, emergency access, the activities of the National Advisory Council for Environmental Policy and Technology (NACEPT) radiation cleanup regulation subcommittee, EPA's low-level radioactive waste standard, and the 3R-STAT method for determination of source term;

- commercialization of federal activities;

- waste from outside the United States, including Department of Defense overseas waste, and the North Atlantic Free Trade Agreement and compact authority;

- early closure of nuclear power facilities including technical failure, unanticipated repairs and/or cost, and legislative actions or electoral initiatives; and

- refurbishing or closing nuclear power facilities, including utility decisions to refurbish or close nuclear power facilities, the state role in affecting utility decisions, waste streams, and future use of closed facility sites.
During the session, the following motions were passed by the LLW Forum. (See "New Materials and Publications.")

Whereas several recent federal actions suggest that low-level radioactive waste which was previously deemed to be a federal responsibility may be disposed of at commercial disposal facilities,

Be it resolved that

The LLW Forum Convenor write immediately to the Secretary of the Department of Energy to notify her that Participants in the LLW Forum are concerned about the proposed use of commercial facilities for the disposal of DOE waste and the privatization of activities formerly conducted by DOE with the potential shifting of waste disposal responsibilities to the states and compacts. The Forum requests that these issues be placed on the agenda of future meetings between Forum Participants and DOE officials.

Whereas importation of waste generated outside of the United States has been raised by the public in a number of areas of the country, and

Whereas the L.S. Nuclear Regulatory Commission initiated a rulemaking on the import and export of radioactive waste in 1990 ,

Be it resolved that

The LLW Forum Convenor write immediately to the Chair of the U.S. Nuclear Regulatory Commission to notify him that Participants in the LLW Forum encourage the NRC to proceed with issuance of revisions to its rulemaking on the import and export of radioactive waste as soon as possible.

(For further information on the special session, see "Getting a Handle on Volumes and Curies: Potential Factors in Long-Range Projections," an excerpt from the LLW Forum spring 1994 meeting report.) 


\section{Pennsylvania Study on Rates of Decay for Classes of Low-Level Radioactive Waste}

Excerpted from the LLW Forum Meeting Report, April 25-27, 1994, prepared by Afton Associates, Inc., pages $35-37$.

\section{New Technique for Analyzing Low-Level Radioactive Waste}

William Dornsife reported on his development of a new analytical technique that is aimed at providing more detail on waste toxicity for specific low-level radioactive waste streams. He noted that the technique, which analyzes what really contributes to waste toxicity, can help explain waste toxicity to non-regulators and members of the public.

Dornsife explained that the traditional way of analyzing low-level radioactive waste streams for annual reports is to provide information on volumes and activity (number of curies) by generator groups. This technique usually shows that nuclear power plants produce the most activity or the largest number of curies. He noted that studying generator groups by waste class provides information on curies, but that is not a good measure of the toxicity of the waste. Another approach is to look at the longevity of the waste, but that also does not accurately describe waste toxicity.

\section{Toxicity depends on the} chemical behavior of the specific radionuclide when it enters your body.

Dornsife said that toxicity depends on the chemical behavior of the specific radionuclide when it enters your body. For example, some radionuclides seek out the bones of a living organism and may also concentrate in critical organs.
Dornsife explained the new system he developed to analyze data for the Pennsylvania annual report on lowlevel radioactive waste generated in the Commonwealth. He said that his system recognizes that ground water is the critical pathway. It takes radionuclide activity, divides it by volume, divides again by the EPA standard drinking water limit (a dose of 4 millirem per year, assuming a person drinks two liters per day) and results in a measure of intrinsic toxicity. The result is a measure of the comparative intrinsic geotoxicity of low-level radioactive waste.

Dornsife noted that he has developed a simple LOTUSbased IBM computer program for plugging in activities and volumes including information on generator, class, nuclide, and total activity per class.

\section{Application of the System to Pennsylvania Data}

Dornsife then demonstrated how the system measures toxicity using radium as an example. Using the system, Dornsife found that, for most class A low-level radioactive waste, the rate of toxicity is flat after 300 years. He also found that, in analyzing the 1992 Pennsylvania waste stream, radium was the biggest contributor to toxicity in all classes of waste. The radium in the waste was primarily generated by the medical class of generators. Waste from the Three Mile Island II reactor accident also was a major contributor to long-term toxicity. Neither of these waste streams will be disposed of at the Pennsylvania facility.

Using the same system, Dornsife also found that radium also predominates the toxicity in class $\mathrm{C}$ low-level radioactive waste. 


\section{LLW Forum continued}

Dornsife then made the following additional points about the system and his findings for 1992 Pennsylvania waste.

- The system can be used to compare the toxicity of classes A, B, and C low-level radioactive waste with soil.

- His findings show that, in Pennsylvania, the longterm toxicity of class A and B wastes are almost identical.

- Using a very low estimate for low-level radioactive waste generated by non-nuclear entities, most toxicity from radium medical waste.

- His findings show that, looking at relative contributions of low-level radioactive waste per generator for toxicity, the radium disposed by the medical generators have the highest toxicity of all of the waste.

- If the waste generated by the one-time occurrence at Three Mile Island is subtracted, nuclear power plants rank very low in terms of long-lived toxicity.

- The program and system allow regulators to estimate a "realistic" source term, subtracting one-time occurrences and kinds of waste that will be excluded, such as sealed sources.

- The system demonstrates that the only isotope in nuclear power plant class A waste that exceeds soil toxicity is carbon 14 .

- The system can take into consideration revised estimates of iodine 129 in calculations because it is general knowledge that generator estimates for this isotope are over inflated.

- Findings on class $\mathrm{C}$ waste show that after 500 years toxicity is dominated by long-lived radionuclides that are low-energy beta emitters. It is therefore difficult for living organisms to be exposed at significant levels since the form of the waste is metal and therefore very stable and a minimal threat to public health and safety.
Dornsife also noted that both EPA and the National Council on Radiation Protection are in the process of developing classification systems based on total hazard including chemicals, not just curies. In response to questions he added the following information.

- While the presentation was based on actual waste streams, the system can be used for projected waste streams.

- This information is being presented for the first time at the LLW Forum meeting.

- Drinking water limits use common risk factors for all radionuclides and therefore is an appropriate yardsuick for the ground-water pathway.

- Medical wastes' hazard exceeded nuclear power plant wastes' hazard for all waste streams when radium was included, but most radium sealed sources will not be sent to a low-level radioactive waste disposal facility in Penusylvania.

- Under any realistic scenario, industrial low-level radioactive waste will most likely dominate the long-term toxicity compared to other low-level radioactive waste generators

\section{Under any realistic scenario,} industrial low-level radioactive waste will most likely dominate the long-term toxicity compared to other low-level radioactive waste generators. 


\section{States and Compacts}

Northwest Compact/Washington

\section{Stohr Named Executive Director of Northwest Compact}

On May 1, Joe Stohr was appointed to the position of Executive Director of the Northwest Interstate Compact on Low-Level Radioactive Waste Management. Immediately prior to his appointment, Stohr managed the Technical and Regulatory Section of the Washington State Department of Ecology, overseeing the Hanford cleanup and commercial low-level radioactive waste management. Stolir joined the High-Level Waste Office of the Department of Ecology in 1986. Before joining the Department of Ecology, Stohr served with the Washington State Department of Health from 1982 to 1986 , where he regulated the US Ecology facility at Hanford. He has a master's degree in radiation health physics.

Stohr replaces Elaine Carlin, who left her position as Executive Director of the Northwest Compact at the end of April. It was noted at the spring meeting of the LLW Forum that through the years Carlin has been a very able representative of Washington and the sited states, as well as being an important contributor to the work of the LLW Forum, the LLW Forum Executive Committee, and the LLW Forum Mixed Waste Working Group. All Participants in the LLW Forum joined in wishing her well.

\section{Southeast Compact/North Carolina/South Carolina}

South Carolina Legislature Adjourns without Extending Access to Barnwell for Outof-Region Generators

On June 2, the South Carolina legislature adjourned without extending access to the low-level radioactive waste disposal facility located in Barnwell, South Carolina. Although an early version of the budget passed by the Senate added revenues from waste disposal by generators outside the Southeast Compact, the final budget passed by both houses of the legislature on June 2 did not include these revenues. Neither the House nor the Governor of South Carolina had included revenues from out-of-region generators in their budget proposals this year.

Contracts between the Southeast Low-Level Radioactive Waste Compact Commission and other compact commissions and unaffiliated states for access to the Barnwell facility expire on June 30,1994 . South Carolina law and Southeast Compact policy provide that waste from outside the Southeast Compact will not be accepted at the Barnwell facility after this date. According to an official from the South Carolina Governor's office, there is no other vehicle for allowing an extension of access.

Barnwell will continue to serve as the Southeast Compact's regional low-level radioactive waste disposal facility until January 1, 1996. A new regional disposal facility, which will accept low-level radioactive waste from only Southeast Compact member states, is scheduled to open in North Carolina in 1996.

For further information, contact Ted Buckner of the Southeast Compact Commission at (919)821-0500 or Carl Roberts of the South Carolina Governor's Division of Natural Resources at (803)734-0543.

Much of the preceding information was distributed to Forum Participants/Alternates and Federal Liaisons/Alternates via facsimile transmission in a News Flash on June 2. 


\section{Southeast Compact Commission Authorizes Payments for Facility Development Also Votes on Petitions, Access Contracts}

The Southeast Low-Level Radioactive Waste Compact Commission voted on April 29 to expedite cash payments to the compact region's next host state, North Carolina. The expedited payments are allocated for facility development costs up through licensing. Funds in the amount of $\$ 30$ million had previously been allocated for this phase of facility development, but payments had been limited to $\$ 3$ million per quarter. Money for the payments is provided by fees collected from generators within the compact region.

In addition, the compact voted to provide $\$ 7$ million from its general treasury for pre-construction planning. This phase of facility development was originally to have been funded through revenue bonds or private debt financing. The commission's action is intended to ensure that the North Carolina Low-Level Radioactive Waste Management Authority will have cash in hand to allow ground-breaking on facility construction as soon as a license is issued.

Compact Commission staff have described the commission's action as a demonstration of confidence in North Carolina's program for facility development.

\section{No Exemption for Defense Waste from California}

In other action at the meeting, the Southeast Commissioners ruled on petitions from generators for exemptions from the compact commission's import policy. Among the petitioners was the Mare Island Naval Shipyard in California, which had requested a waiver from premium access fees assessed on excess waste disposed of at the compact's regional low-level radioactive waste disposal facility at Barnwell, South Carolina. Specifically, the compact commission was asked to allow disposal of an additional 7,200 cubic feet of low-level radioactive waste from the shipya-d without assessing a premium of approximately $\$ 500,000$ in addition to the regular access fees. This request was denied, with compact commissioners citing lack of "extraordinary circumstances" needed to justify an exemption. In discussion prior to the vote, commissioners also expressed frustration with perceived intervention and delay by the federal government in the development of a regional low-level radioactive waste disposal facility in Ward Valley, California.

\section{Access for Rocky Mountain Compact and Maine}

Also on April 29, the Southeast Commissioners authorized execution of an access contract with the Rocky Mountain Low-Level Radioactive Waste Board. The contract will allow for disposal of approximately 70 cubic feet of low-level radioactive waste being stored in the Rocky Mountain Compact region by waste broker RAMP, Inc. Because the waste in question originated outside the Rocky Mountain Compact region, the waste is not eligible for disposal at the facility in Hanford, Washington, under the board's agreement with the Northwest Interstate Compact on Low-Level Radioactive Waste Management and the state of Washington.

The Southeast Compact Commission did not act on an application by Rhode Island for a determination of access eligibility, and no further meetings of the commission are anticipated prior to the expiration of all extant contracts on June 30, 1994.

An access contract was previously executed with the state of Maine on April 15, following passage of legislation in Maine to allow the agreement. The new Maine law allows for disposal at Barnwell of waste only from the Portsmouth Naval Shipyard.

Forfurther information, contact Sherol Bremen of the Southeast Compact Commission at (919)821-0500. 


\section{States and Compacts continued}

\section{Southwestern Compact/California}

\section{Storage of Low-Level Radioactive Waste at Rancho Seco Removed from Consideration}

According to recent articles in the California press, the Sacramento Municipal Utility District (SMUD) has decided against an idea to store low-level radioactive waste at the closed Rancho Seco nuclear power plant near Sacramento, California. SMUD officials were approached with the idea last month byinterest groups, including the Committee to Bridge the Gap, who requested that SMUD consider storing the waste in a specially designed building at Rancho Seco that already contains low-level radioactive waste. Upon publication of the idea in the media, various state and federal officials voicen their concern over and opposition to the use of Rancho Seco as a waste storage facility.

\section{Compact Commission}

The Southwestern Low-Level Radioactive Waste Compact Commission notified SMUD, by letter dated May 3, that SMUD's consideration of the Rancho Seco option constitutes "conduct that can properly be classified as the management of the Southwestern Compact Region's low-level radioactive waste." The commission noted that the management of such waste is the commission's legal responsibility and that other government agencies-including SMUD-do not have authority to act in this area unless they first obtain formal approval from the commission.

The [Southwestern] Compact mandates that low-level radioactive waste generated within the region shall be disposed of at a regional disposal facility. Regional disposal facility means a nonfederal low-level radioactive waste disposal facility established and operated under the Compact. Furthermore, the Compact prohibits any person from disposing of low-level radioactive waste within the region unless the disposal is at a regional disposal facility.

The commission requested that SMUD provide-by May 20-a statement of authority under which it is considering the storage of low-level radioactive waste at Rancho Seco.

\section{U.S. Representative Matsui}

U.S. Representative Robert Matsui (D-CA) expressed opposition to the idea of storing waste at Rancho Seco in letters to California Governor Pete Wilson and to Ivan Selin, Chair of the U.S. Nuclear Regulatory Commission (NRC). In his letter to Selin, Matsui asks, "[I]f remote Ward Valley-the proposed low-level radioactive waste disposal facility located in the deserts of Southern California-is not safe enough for storing low-level nuclear waste, how can we consider storing waste in Sacramento, a community of 1.2 million people?" According to Matsui, there are many reasons to oppose storage of radioactive waste at Rancho Seco.

- The facility is located nearvarious rivers and creeks, and there are many wetlands in the vicinity.

- Although proponents are promoting Rancho Seco as a temporary storage place for short-lived radioactive waste, " $[\mathrm{i}] \mathrm{t}$ is easy to envision a not-toodistant future when the storage crisis mounts even higher and more dangerous waste is allowed to enter Rancho Seco."

- If waste is only to be temporarily stored at Rancho Seco, the problem remains of where it will be taken for final disposal.

- There are risks that would be posed by transportation of waste to and from the facility. 


\section{States and Compacts continued}

\section{Governor Wilson}

California Governor Pete Wilson responded to Representative Matsui by letter dated May 10, stating, "I agree with you that this proposal is ill-conceived and join with you in rejecting it as a useful or viable alternative."

Wilson offered several reasons why he believes that storage of waste at Rancho Seco is not a viable option.

- Since the facility would not take all classes of lowlevel radioactive waste, and since it is not likely to be approved by the Southwestern Compact Commission as a replacement for Ward Valley, it would be required to take waste from every state around the country under the Interstate Commerce Clause of the U.S. Constitution and the U.S. Supreme Court opinions interpreting that clause. Any waste accepted from outside the Southwestern Compact region may have to remain at Rancho Seco.

- Since storage oflow-level radioactive waste at Rancho Seco is seen by many of its supporters as an alternative to Ward Valley, the Rancho Seco facility will either take only waste of such short-lived radioactivity that storing the waste will be of little benefit, or the facility will become a de facto disposal site.

- "Precisely what makes Rancho Seco a good site for a nuclear power plant, the availability of ample water for cooling purposes, makes it a bad disposal site."

\section{NRC Chair Selin}

In a May 18 letter to Representative Matsui, NRC Chair Ivan Selin stated that a formal licensing request would need to be submitted to the NRC before Rancho Seco could accept low-level radioactive waste for storage. The evaluation of such a request, according to Selin, would require $\mathrm{NRC}$ staff to take the following generic considerations into account.

- A long-standing policy that "opposes any activity at a nuclc ar reactor site that is not generally supportive of activities authorized by the operating license or construction permit and that may divert the attention of licensee management from its primary task of safe operation or construction of the power reactor." Selin said that the commission would consider applying this policy to Rancho Seco, even though the power plant is not operating, in order to ensure that storage of waste at the site would not have an adverse impact on public health and safety.

- A long-standing position of the NRC that favors disposal over storage.

Selin pointed out that storage of waste at Rancho Seco would require consultation with state and regional compact low-level radioactive waste officials and that California's status as an Agreement State would have important licensing implications.

Selin also noted that

storage of byproduct material produced by other licensees would require that the NRC issue a license ... In addition, the existing 10 CFR Part 50 reactor license would be subject to review and possible amendment, to ensure that none of the Part 30 waste storage activities could impact decommissioning efforts in a manner that would adversely affect protection of public health and safety. 


\section{Special Feature: Plutonium Estimates for Ward Valley}

\section{Plutonium Estimates for Ward Valley, California}

In recent months, U.S. Senator Barbara Boxer (D-CA) and various facility opponents have raised a number of issues regarding the amount of plutonium 239 to be disposed of at the Ward Valley low-level radioactive waste disposal facility. The following are quotations concerning these issues taken from various letters and count documents, as cited:

\section{Amount of Plutonium to be Disposed of at Ward Valley Facility}

\section{Issue}

"We now know that the waste stream representations made by [the Department of Health Services (DHS)] during the public review process were false ... The amount of Plutonium-239, for example, is increased over 7,000-fold, from 0.45 curies to 3,500 curies." (Letter from U.S. Senator Barbara Boxer to California Governor Pete Wilson. March 17, 1994.)

\section{Response}

"[T] he 3,500 curies of plutonium is not a waste stream projection but a deliberately much exaggerated overestimate which DHS used to err heavily on the side of safety. As described throughout the Administrative Record, .45 curies is the waste stream actually projected from historical data. The analysis based on 3,500 curies represents a conscious effort to assure over-capacity and safeguards far, far beyond possible need, to account for some uncertainty concerning decontamination wastes." (Letter from California Governor Pete Wilson to U.S. Senator Barbara Boxer. April 27, 1994.)
"Based on review of historic waste shipment records, the License Application submitted to DHS in January 1990 projected that approximately .45 curies of plutonium-239 from normal reactor operations and non-fuel cycle waste producers would be received for disposal during the 30 year operating life of the Ward Valley facility ... In fact, less than one-tenth of one curie of plutonium-239 waste from all sources was actually shipped for disposal from the Southwestern Compact region from 1988-1992. While decontamination and decommissioning wastes may add some additional plutonium, it will not approach 3,500 curies.

The approximately 3,500 curie figure ... was used for regulatory safety analysis purposes only. Since no primary coolant loop decontamination has ever been performed on a nuclear power reactor in the Southwestern Compact region, US Ecology conservatively estimated (i.e.. purposely overestimated) such wastes ... A U.S. Nuclear Regulatory Commission decommissioning document identifying decontamination wastes produced by the Dresden One nuclear power plant in Illinois ... was the source for the estimate presented in ... [a table in the license application], which reflects 303,872 curies of decontamination waste; 3,447 curies of which were plutonium-239.

As is consistently stated in the EIR/S, the License Application, and our licensing interrogatory response, 303,875 curies of decontamination wastes, including approximately 3,500 curies of plutonium-239, were employed for analysis purposes to provide a wide margin of safery in analysis of the site's performance-not for purposes of projecting actual waste receipt." (Letter from Stephen Romano, Vice President, US Ecology, to U.S. Senator Barbara Boxer. March 30, 1994.) 


\section{Special Feature: Plutonium Estimates for Ward Valley continued}

\section{Use of Plutonium Figures in the Environmental Analysis \\ Inclusion of Plutonium Figures in the Public Record}

\section{Issue}

"Because ... information was omitted from its EIR, DHS failed to assess the significant impact on the environment posed by the higher levels of plutonium-239 and other wastes in violation of ... [California Environmental Quality Act] guidelines." (Joint memorandum by petitioners in City of Needles $v$. Califormia Department of Health Services and Fort Mojave Indian Tribe v. Califormia Department of Health Services. March 9, 1994.)

\section{Response}

"The record clearly shows all [plutonium 239] amounts, including the overestimate developed for safety analysis purposes, were included [in the environmental analysis]." (Memorandum by state respondents in City of Needles v. Califormia Department of Health Services and Fort Mojave Indian Tribe 2. Califomia Department of Health Services. April 6, 1994.)

\section{Issue}

"Last December, long after the public comment period had closed on the project, and after DHS had issued a license to US Ecology to operate the nuclear waste facility, DHS released the project's Administrative Record which contains significant information about the waste stream never before seen by the public." (Letter from U.S. Senator Barbara Boxer to California Governor Pete Wilson. March 17, 1994.)

\section{Response}

"The Administrative Record on which the licensing decision is based was made available to the public as it was developed, much of it now having been public record for several years." The amount of plutonium239 used for regulatory safety analysis purposesapproximately 3,500 curies-is "mentioned in the License Application, which has been in the public record since January 1990, and was printed in full in the Administrative Record." (Letter from California Governor Pete Wilson to U.S. Senator Barbara Boxer. April 27, 1994.)

The letter from Senator Boxer "incorrectly claims the DHS first revealed its analysis of approximately 3,500 curies of plutonium-239 in December 1993, three months after the license was issued. In fact, that same figure was presented in Appendix Table 61 10.B-10 of the completed License Application submitted by US Ecology to DHS (and therefore available to the public at DHS) in January 1990 ... The License Application was placed in public document repositories established throughout the State in mid 1991, prior to public hearings on the project and more than two years before facility license approval." (Letter from Stephen Romano, Vice President, US Ecology, to U.S. Senator Barbara Boxer. March 30, 1994.) 


\section{Courts}

City of Needles v. Califormia Department of Health Services

Fort Mojave Indian Tribe v. California Department of Health Services

\section{Judgment Issued in Ward Valley Lawsuits}

On June 1, the Superior Court of the State of California issued a judgment in two lawsuits seeking to void the license granted to US Ecology to construct and operate a low-level radioactive waste disposal facility in Ward Valley, California. The judgment orders the respondents-Department of Health Services (DHS) and its Director-to take certain actions consistent with the court's May 4 order in the same lawsuits.

\section{The Judgment}

On May 12, the petitioners filed a proposed judgment and writ with the superior court for its consideration. The state respondents filed an objection to the proposed judgment and writ on May 20, arguing that neither of the proposed documents is appropriate for consideration by the court at this time and that both documents exceed the scope of the court's May 4 order, are inconsistent with the order, and are incomplete. On May 26, US Ecologyjoined the state respondents' objections.

The court signed the proposed judgment on June 1. However, the court added language to the judgment in accordance with certain objections raised by the respondents in their May 20 pleading. As issued, the judgment remands the case to DHS so that it may review and evaluate a December 1993 report, referred to as the "Wilshire Report" after one of its three authors. (The authors are scientists employed by the U.S. Geological Survey, but the report states that it "does not represent the policies or positions of any government agency.")

\section{The Substantial Evidence Rule and the Independent Judgment Test}

'Under the 'substantial evidence rule,' reviewing courts will defer to an agency determination so long as, upon an examination of the whole record, there is substantial evidence upon which the agency could reasonably base its decision." (Black's Law Dictionary) Under the independent judgment test, however, reviewing courts may exercise their own judgment in making a determination in the face of conflicting evidence in the administrative record. The independent judgment test sill permits the court to defer to the expertise of the agency.
Specifically, DHS is required to

- "reconsider its approval of the license issued under [the Radiation Control Law] to real party in interest U.S. Ecology, Inc., in light of the Wilshire Report," and

- "consider whether a new hearing or recirculation of a subsequent [environmental impact report] is required or desirable under [the California Environmental Quality Act]."

Under the terms of the judgment, DHS must "[s]et aside its approval of this project ... pending this reconsideration" and "suspend all approvals or activities relating to this project that could result in any change or alteration to the physical environment" until the reconsideration has been completed.

According to DHS officials, the department has already initiated a review and evaluation of the Wilshire Report as directed by the court.

\section{The Court's May 4 Order}

The order issued by the superior court on May 4 found that virtually all of the grounds raised by the petitioners for contesting the licensing process are "without merit." However, the court also decided that the Wilshire Report constitutes "significant new scientific analysis." The court ordered the California Department of Health Services (DHS) to consider the report-which was distributed after the Ward Valley license was approvedas though it had been issued prior to the license approval.

Standard of Review In issuing its decision, the court had to determine which standard of review to apply: the substantial evidence rule or the independent judgment test. Generally, the standard of review for a case contesting a licensing decision would be substantial evidence. However, the court determined that the unique position and rights of petitioner Fort Mojave Indian Tribe compelled the application of the independent judgment test. 


\section{Courts continued}

Accordingly, the court deemed the Wilshire Report to be "highly technical" and, as permitted, the court admitted this new evidence and remanded it to the agency for consideration.

Claims Determined to be Without Merit The superior court determined that most of the petitioners' grounds for contesting the California Environmental Quality Act (CEQA) and the licensing process are "without merit." In this regard, the court ruled that

- DHS' determination that US Ecology is qualified to operate the disposal facility is well founded;

- the petitioners failed to establish that US Ecology made any misrepresentations in its license application (for instance, the petitioners had claimed that the total disposal quantities of radionuclides, such as plutonium, were misrepresented in the application);

- the petitioners failed to establish that the license application was not adequately made available for review;

- there was no improper denial of a request for party status from any of the petitioners;

- the designation of the Ward Valley site as critical habitat for the desert tortoise subsequent to DHS' issuance of a license is not sufficient reason to void the license because critical habitat status was assumed during the administrative process and because the license adopts viable mitigation measures;

- the adoption of regulations for the licensing hearing is not required by statute, but rather permitted, and no evidence was submitted indicating that California failed to follow their own hearing procedures; and

- the use of Rock Valley data (an adjacent and similar geology), combined with testing at Ward Valley, was a sufficient and proper means of analyzing water infiltration at the proposed site.
The Wilshire Report The court decided that the December 1993 report prepared by three geologists who work at the U.S. Geological Survey constitutes "significant new scientific analysis" of preexisting data. The report was prepared by the geologists, acting as private citizens, at the request of U.S. Senator Barbara Boxer (D-CA). (See LLW Notes, Winter 1993, pp. 14 16.) The court recognized that DHS has responded to the issues raised in the report-which was completed after approval of the license application-but decided that the importance of the licensing decision requires further consideration of the report.

The court does not doubt that an evaluative process has been applied to the Wilshire Report by respondent ... however, the report should be evaluated in a pre-approval setting in order to give CEQA its full reign.

In so ruling, the court recognized "that submission of the Wilshire Report at this state of the proceedings is highly unusual and an adequate explanation for the timing thereof has not yet been presented." However, the court determined that since the federal government has not resolved issues related to the proposed transfer of the Ward Valley site to the state of California, the overall administrative process is not yet complete, and DHS reconsideration of the report would not result in significant prejudice to the respondents.

The court limited the scope of California's reconsideration of the licensing decision to issues raised by the Wilshire Report.
Respondents are not required to have an entire renewal of the CEQA or licensing process unless it is necessary to give full exposure and evaluation to the Wilshire Report. The report is significant new "analysis," not data. It does not change the project, nor does its presence deprive the public of a meaningful opportunity to comment.

The order states, "Whether a new hearing or recirculation of a 'subsequent' [Environmental Impact Report] is required or desirable is to be considered by respondents."

The order specifies that the petitioners may be required to pay for the added cost of reconsideration of the report by DHS given the unusual timing of the report's submission. This question may be addressed at a later stage in the proceedings. 


\section{Courts continued}

\section{Background}

The Parties On October 15, 1993, several groups filed a lawsuit-FortMojaveIndian Tribev. California Department of Health Services-in California superior court seeking to void the license issued by DHS to US Ecology. The Fort Mojave Indian Tribe, Los Angeles Physicians for Social Responsibility, the Southern California Federation of Scientists, and the Committee to Bridge the Gap are all plaintiffs in the action. The California Department of Health Services and its Acting Director are listed as defendants, and US Ecology is identified as a real party in interest to the action. At a hearing on December 8,1993 , the court granted a motion by the California Radioactive Materials Management (Cal Rad) Forum to intervene in the action as a real party in interest.

A similar lawsuit-City of Needles v. California Department of Health Services-was filed in the same superior court on October 20, 1993. DHS and the California Health and Welfare Agency are named as defendants to the action, and US Ecology is identified as a real party in interest. (See LLW Notes, Winter 1993, pp. 20-23.)

The superior court ruled that the cases are similar and should be heard by the same judge, although the cases have not been formally consolidated.
The Issues The lawsuits seek to void the license for the planned Ward Valley facility on the grounds that the respondents violated CEQA, the California Radiation Control Law, and the Southwestern Compact during the licensing process. (See LLWNotes, Winter 1993, pp. 20-23.)

Previous Order On February 7, 1994, the superior court granted a motion for summary adjudication filed by US Ecology and joined by the state defendants. The court ruled that while the California Health and Safety Code requires the state to hold a hearing on the record prior to issuing a license for the planned facility, the state does not h..ve a duty to provide either an "adjudicatory" hearing or a hearing as described in the Administrative Procedure Act. The court did not rule on the adequacy of the hearing previously held by the California Department of Health Services, or on other claims raised by the plaintiffs relating to the validity of the licensing decision, because these issues were not raised by US Ecology in its motions. (See LLW Notes, February/March 1994, pp. 22-23.)

For a more detailed description of the issues involved in these lawsuits, see "Ward Valley, Califomia: Legal Issues in Summary, " LLW Notes Supplement, May/June 1994

Some of the preceding information was distributed to Forum Participants/Alternates and Federal Liaisons/Alternates via facsimile transmission in a News Flash on May 9.

\section{Other News}

\section{Host State Technical Coordinating Committee Meets}

The Host State Technical Coordinating Committee (TCC) met in St. Louis, Missouri, on April 14 and 15. An Afton staff member, who serves as the LLW Forum liaison to the TCC, attended to present a report on L.WW Forum activities. The following topics constituted the agenda:

- state highlights and reports;

- agency and organizational reports;

- a report developed by Ebasco on lessons learned from the Illinois Low-Level Radioactive Waste Disposal Facility Siting Commission;

- the U.S. NRC's draft branch technical position on performance assessment;
- a presentation by a U.S. Geological Survey representative on a study of carbon-14 migration;

- a presentation on final waste forms for low-level mixed waste; and

- a tour of the Illinois Department of Nuclear Safety's Radiological Emergency Assessment Center.

The TCC directed staff to draft a letter to the Nuclear Regulatory Commission asking NRC to assign its highest priority to the review of the 3R-STAT computer code topical report. The TCC plans to meet again on July 25 and 26 in Seattle, Washington.

For further information, contact TCC Co-Moderator Tom Kerr, National Low-Lavel Waste Management Program, (208)526-8465. 


\section{Courts continued}

Central Midwest Interstate Low-Level Radioactive Waste Commission v. O'Leary

\section{Central Midwest Commission Questions Court's Jurisdiction Over Surcharge Rebates Litigation}

On April 18, the Central Midwest Interstate Low-Level Radioactive Waste Commission filed a memorandum of law regarding the substantive jurisdiction of the United States District Court of the Central District of Illinois over a lawsuit concerning the distribution of surcharge rebates. (See LLW Notes, April 1994, p. 20.) Jurisdiction is a legal term referring to the authority of a court to hear and determine a particular class of cases. In its memorandum, the commission states that it believes that the district court has jurisdiction over the rebate issue, but it analyzes the possibility that jurisdiction may actually be vested in the federal circuit court of appeals. According to the commission, the analysis is offered so as to resolve this issue early in the litigation. The Department of Energy and Commonwealth Edison, an intervenor in the action, filed responses in May arguing that the district court has jurisdiction over the case. As of press time, the court has not issued a ruling in response to the memorandums.

\section{Commission's Memorandum}

The commission's April 18 memorandum raises the issue of whether the federal circuit court of appeals may have exclusive jurisdiction over this case under the Hobbs Act, a statute that governs review of certain federal agency decisions. The commission notes that the statute may give the appeals court exclusive jurisdiction over actions of the Department of Energy that are taken in accordance with the Low-Level Radioactive Waste Policy Amendments Act, if the actions deal with the activities of licensees. The commission acknowledges that Commonwealth Edison Company and Illinois Power Company-both of which are intervenors in the present action-are licensees and that the recent Federal Register notice on surcharge rebates appears to "deal with" their activities.
However, the commission states that it "believes that the decisions of the Secretary of Energy with respect to the surcharge rebates do not regulate the activities of the potential claimants because of their status as licensees of the U.S. Nuclear Regulatory Commission, but because of their status as potential claimants to the trust funds held by the Secretary." Accordingly, the commission notes that it believes that the district court has jurisdiction over this matter.

\section{DOE's Memorandum}

In a memorandum filed on May 6, the Department of Energy argues that the Hobbs Act is not applicable to the present case. According to the department, the cases cited in the commission's April 18 memorandum were governed by the Hobbs Act because they involve challenged rules or orders that were established pursuant to a federal agency's authority under the Atomic Energy Act. In the present case, however, the challenged regulations concerning the eligibility criteria and procedures for distributing surcharge rebates were not established under the Atomic Energy Act. Instead, argues the department, they were established under the Low-Level Radioactive Waste Policy Act and its 1985 amendments. Accordingly, the department argues that the Hobbs Act is not applicable and that jurisdiction is not vested in the court of appeals.

\section{Next Step}

The parties to this lawsuit are currently working on a stipulated order to be presented to the court under which the Department of Energy would agree not to distribute escrow moneys that may be affected by the outcome of this action. As of press time, the parties have not issued the final language for the stipulated order. 


\section{Courts continued}

Oregon Waste Systems, Inc. v. Department of Emvironmental Quality of the State of Oregon

\section{Supreme Court Decides Commerce Clause Case Involving Solid Waste}

On April 4, the United States Supreme Court found to be unconstitutional a surcharge of $\$ 2.50$ per ton imposed by the state of Oregon on the in-state disposal of solid waste generated outside of the state. The decision may be of interest to those in the low-level radioactive waste field because of its implications for fee differentiation and exclusionary authority.

\section{Background}

The Facts The state of Oregon imposes various fees on landfill operators in order to fund the state's regulation of solid waste disposal within its borders. In 1989, the Oregon legislature decided to impose a surcharge on the disposal of waste generated outside the state. The legislature directed the state Environmental Quality Commission to set the amount of the surcharge "based on the costs to the State of Oregon and its political subdivisions of disposing of solid waste generated outof-state which are not otherwise paid for" under specified statutes. The commission set the surcharge at $\$ 2.25 \mathrm{per}$ ton. At the same time, the legislature imposed a feecapped by statute at $\$ 0.85$ per ton-on the in-state disposal of waste generated within Oregon. The fee of $\$ 0.85$ per ton was eventually extended to out-of-state waste, in addition to the surcharge of $\$ 2.25$ per ton, under the condition that if the surcharge survived judicial challenge, the fee of $\$ 0.85$ per ton would again be limited to in-state waste.

The Parties Shortly thereafter, Oregon Waste Systems, Inc. and Columbia Resource Company, joined by the Oregon county of Gilliam, filed suits seeking expedited review of the out-of-state surcharge. Oregon Waste owns and operates a solid waste landfill in Gilliam County that accepts waste generated both within and outside of the state. Columbia Resource Company transports out-of-state waste to an Oregon landfill. The state Department of Environmental Quality and the Environmental Quality Commission were named as defendants to the actions.
Lower Court Decisions The Oregon Court of Appeals upheld the statutes and administrative rule establishing the out-of-state surcharge. The court held that the surcharge is not facially discriminatory, since it is based upon actual costs incurred by state and local government. The State Supreme Court affirmed the decision.

\section{The Opinion}

Associate Justice Clarence Thomas authored the opinion, joined by Associate Justices Paul Stevens, Sandra Day O'Connor, Antonin Scalia, Anthony Kennedy, David Souter, and Ruth Bader Ginsburg. The Court found that the out-of-state surcharge violates the Commerce Clause and reversed the Oregon Supreme Court.

\section{The Commerce Clause}

Article I, Section 8, Clause 3 of the United States Constitution provides that Congressas opposed to the states-has the power to regulate commerce with foreign nations, and among the several states, and with Indian Tribes.

The "negative" Commerce Clause-often discussed in cases such as these-refers to limits on state action to regulate or tax in a manner that would impermissibly burden or discriminate against interstate commerce, even in areas where Congress has not acted. 


\section{Courts continued}

\section{Is Oregon's Law Discriminatory?}

In reaching its decision, the Supreme Court relied on Chemical Waste Management, Inc. v. Hunt-a 1992 case in which the Court found that an Alabama state law that places an additional disposal fee of $\$ 72$ per ton on hazardous waste generated outside the state but disposed of at commercial hazardous waste facilities in the state violates the Commerce Clause of the U.S. Constitution. (See LLW Notes, May/June 1992, pp. 12-16.)

In Chemical Waste, we easily found Alabama's surcharge on hazardous waste from other States to be facially discriminatory because it imposed a higher fee on the disposal of out-of-state waste than on the disposal of identical in-state waste ... We deem it equally obvious here that Oregon's $\$ 2.25$ per ton surcharge is discriminatory on its face. The surcharge subjects waste from other States to a fee almost three times greater than the $\$ 0.85$ per ton charge imposed on solid in-state waste. The statutory determinant for which fee applies to any particular shipment of solid waste to an Oregon landfill is whether or not the waste was "generated out-of-state"... It is well-established, however, that a law is discriminatory, ifit "tax [es] a transaction or incident more heavily when it crosses state lines than when it occurs entirely within the State."

The Court rejected Oregon's argument that the statutory nexus between the surcharge and the otherwise uncompensated state and local cost of disposing of outof-state solid waste precludes a finding that the surcharge is discriminatory. Referring back to its decision in Chemical Waste, the Court noted that "the purpose of, or justification for, a law has no bearing on whether it is facially discriminatory." In response to the dissent's argument that the amount of the surcharge is to small to be deemed discriminatory, the majority points out that the Court's precedents "clearly establish that the degree of a differential burden or charge on interstate commerce 'measures only the extent of the discrimination' and 'is of no relevance to the determination whether a State has discriminated against interstate commerce."
When Must Discriminatory Laws Be Struck Down? The Court explained that laws that discriminate on their face against out-of-state commerce must be struck down unless they can be shown to advance a legitimate local purpose that cannot be adequately served by reasonable non-discriminatory alternatives. In this particular case, the court noted that Oregon did not argue

- that the disposal of waste generated in other states imposes higher costs on Oregon and its localities than the disposal of in-state waste, or

- that the flow of out-of-state waste into Oregon should be discouraged due to safety and health reasons unique to wastes from other states.

\section{Is the Surcharge a "Compensatory Tax"?}

Oregon's principal defense of its law is that the surcharge is a "compensatory tax" imposed to make shippers of out-of-state waste pay their "fair share" of the costs incurred by Oregon for disposal. In Chemical Waste, the Court had noted that this type of argument may provide a possible justification for a discriminatory surcharge on out-of-state waste. In addition, the Court's decisions in other cases suggest that "a facially discriminatory tax that imposes on interstate commerce the rough equivalent of an identifiable and 'substantially similar' tax on intrastate commerce does not offend the negative Commerce Clause."

The Court rejected Oregon's characterization of the law as a "compensatory tax," noting that Oregon does not impose on shippers of in-state waste a specific charge of at least $\$ 2.25$ per ton, for which the out-ofstate surcharge could be considered compensatory. Oregon and the dissent argue that the surcharge is compensatory for general taxation of intrastate commerce. However, the majority notes that

- general tax payments are used for general purposes of the government and cannot be easily separated out;

- general taxation and the out-of-state surcharge cannot be considered levies imposed on substantially equivalent events; and

- shippers of out-of-state waste probably pay state income taxes, a portion of which mav be used to pay for waste reduction activities in those states, even though the states are not providing disposal.

continued on page 22 


\section{Courts continued}

\section{Is the Surcharge a Cost-spreading Technique?}

Oregon's final argument is that the law is justified because Oregon has a valid interest in spreading the costs of disposal of Oregon waste, but not of out-of-state waste, to all citizens of Oregon. Oregon claims that this interest is realized by a higher general tax burden to support the disposal of waste generated within the state, and by the surcharge for wast e generated outside the state. The Court rejected this argument, finding that Oregon's law incorporates an illegitimate protectionist objective because it results in shippers of out-of-state waste bearing the full costs of disposal, while shippers of in-state waste bear less than the full cost. In response to Oregon's claim that this is resource protectionism, not economic protectionism, the Court stated:

Recharacterizing the surcharge as resource protectionism hardly advances [Oregon's] cause, however. Even assuming that landfill space is a "natural resource," "a State may not accord its own inhabitants a preferred right of access over consumers in other States to natural resources located within its borders."

The Court recognized that "the Commerce Clause does not prohibit all state action designed to give its residents an advantage in the marketplace, but only action of that description in connection with the State's regulation of interstate commerce. "Since in this case the law is facially discriminatory and is clearly connected to the regulation of interstate commerce, the Court found that it has "no occasion to decide whether Oregon could validly accomplish its limited cost-spreading through the 'market participant' doctrine ... or other means unrelated to any regulation of interstate commerce."

\section{The Dissent}

Chief Justice William Rehnquist authored the dissent, which was joined by Associate Justice Harry Blackmun, and which included the following points:

- The surcharge of $\$ 2.25$ per ton is so small that it cannot be deemed discriminatory.

- In concluding that the surcharge is not a compensatory tax, "The [Court] ... ignores the fact that in-state producers of solid waste support the Oregon regulatory program through state income taxes and by paying, indirectly, the numerous fees imposed on landfill operators and the dumping fee on in-state waste."

- The Court has long acknowledged a distinction between economic protectionism and health and safety regulation of the kind promulgated by Oregon in this case.

- The availability of environmentally sound landfill spaces and the proper disposal of solid waste are justifiable health and safety rationales for discouraging the flow of solid waste into Oregon.

The preceding information was distributed to Forum Participants/Alternates and Federal Liaisons/Alternates via facsimile transmission in a News Flash on April 18. 


\section{Courts continued}

US Ecology v. Northwest Interstate Compact on Low-Level Radioactive Waste Management

\section{Parties Voluntarily Dismiss Envirocare Case}

On March 25, the parties to a lawsuit involving US Ecology, the Northwest Interstate Compact on LowLevel Radioactive Waste Management, and others asked the United States District Court for the Western District of Washington to dismiss the action. The lawsuitwhich was filed on March 10, 1992-challenged the Northwest Compact's decision to allow Envirocare of Utah to receive low-level radioactive waste for disposal as contrary to the U.S. Constitution, various federal statutes, the Northwest Compact Agreement, and a Northwest Compact resolution. (See LLW Notes, May/ June 1992, p. 11.) A dismissal order was entered by the court on March 31, 1994.

\section{The Parties}

The following parties were listed as defendants in the lawsuit: the Northwest Compact; Roger Stanley, former Chair of the compact; Elaine Carlin, the compact's previous Executive Director; compact committee members; the Utah Bureau of Radiation Control and Larry Anderson, its Depuly Director; and the Washington Department of Ecology and its Director, Chuck Clarke.

The U.S. Nuclear Regulatory Commission (NRC) and its Chair, Ivan Selin, were originally named as defendants in the suit, but were orally dismissed in July 1992. (See LLW Notes, August/September 1992, p. 20.) A written order dismissing the NRC and Selin was filed by the court on September 3, 1992.

\section{The Issues}

USEcology operates the Northwest Compact's regional low-level radioactive waste disposal facility, located in Richland, Washington. Waste disposed of at the facility that originates outside of the Northwest Compact region is subject to a surcharge levied by the compact and the state of Washington.
Envirocare owns and operates a disposal site licensed by the Utah Bureau of Radiation Control. According to the complaint, this site is not a regional facility and was originally licensed only to receive naturally occurring radioactive material (NORM). However, in September 1990, Envirocare applied for and subsequently received from the state of Utah a license amendment permitting the receipt and disposal of other materials, including some low-level radioactive waste.

US Ecology objected to Envirocare's acceptance of any low-level radioactive waste. However, on December 5, 1991, the Northwest Compact Committee unanimously voted to issue an order permitting Envirocare to accept limited types of low-level radioactive waste from particular sources. Neither the state of Utah nor the Northwest Compact sought to assess surcharges on outof-compact waste received at Envirocare.

\section{The Pleadings}

US Ecology filed a complaint on March 10, 1992, alleging that the refusal of the state of Utah and the Northwest Compact Committee to levy surcharges on low-level radioactive waste received at the Envirocare facility from sources outside of the Northwest Compact region is unlawful and should be enjoined. The defendants answered the complaint in April 1992. As part of their answer, the compact and state of Washington defendants filed a counterclaim against US Ecology. (See LLW Notes, May/June 1992, p. 11.)

In July 1992, two separate motions to dismiss the lawsuit were filed by defendants to the action. The judge denied both motions on January 5, 1993. (See LLW Notes, February 1993, p. 21.) 


\section{Courts continued}

Burton v. Central Interstate Low-Level Radioactive Waste Compact Commission

\section{Appellate Court Affirms Dismissal of Suit Against Central Commission}

On May 2, 1994, the L'nited States Court of Appeals for the Eighth Circuit affirmed the dismissal of a lawsuit filed by two citizens of Nebraska-Diane Burton and Dawneane Ferry Munn-against the Central Interstate Low-Level Radioactive Waste Commission. The court found that the plaintiffs lack standing to bring the action.

\section{What is Standing?}

Standing is a legal doctrine that "raises the question of whether the litigant is the proper party to bring the lawsuit." In order to establish standing in a federal lawsuit, Article III of the U.S. Constitution requires that a plaintiff must allege (1) an injury in fact, (2) causation, and (3) redressability.

\section{Background}

The Pleadings The lawsuit was filed in the United States District Court for the District of Nebraska in July 1992. It challenged the compact commission's bylaws, rules, and budget as unlawful and in violation of compactlaw. In response, the commission filed a motion to dismiss the action in August 1992. The commission argued, among other things, that the plaintiffs do not have standing to bring the lawsuit. The plaintiffs, however, claimed that they do have standing because as citizens, electors, and utility ratepayers, they have been injured by the compact commission's allegedly unlawful taxing of publicly owned entities (i.e. Nebraska's nuclear utilities). They also argued that Article IV of the Central Compact expands the meaning of standing to include them. (See LLW Notes, October 1992, p. 11.)
The District Court's Order The district court, finding that the plaintiffs lack standing to sue, dismissed the case on February 24, 1993. The court ruled that the plaintiffs only alleged an indirect injury which, even if proved, would be one that is shared by a large group of taxpayers, elertors, and ratepayers. Such injury, the court said, is not sufficient to confer standing. (See LLW Notes. March 1993, p. 14.)

\section{The Appellate Court's Decision}

The court of appeals found that the "[a]ppellants have failed to allege an injury in fact-a concrete and particularized invasion of a legally-protected interestwithin the meaning of Article III" because:

- there is only an attenuated connection between the commission's taxing of publicly owned entities and the interests of the appellants, and

- the complaint fails to show a connection between the bylaw's and rules and any real injuries that the appellants have suffered or will suffer.

The court rejected appellant Munn's claim that she has standing because a utility of which she is a ratepayer increased electricity rates in response to the commission's taxes on low-level radioactive waste. Although the court recognized that increased rates may constitute an injury that is traceable to the commission's conduct, it found that Munn failed to allege that the injury is likely to be redressed by a favorable decision.

In regard to the plaintiffs' claim that Congress expanded standing through Article IV of the Central Compact, the court stated that Congress may not abrogate the minimum constitutional requirements to confer standing. "Because Appellants have not satisfied the threshold, constitutional requirements of Article III, they do not have standing even in light of the broad 'aggrieved party' language of Article IV of the Compact." 


\section{LLW Forum Mixed Waste Working Group Meets}

The Mixed Waste Working Group met on April 21 in conjunction with the LLW Forum meeting.

\section{FFCA Task Force and Commercial Mixed Waste}

Teresa Hay, who serves as a member of the FFCA State/ DOE Task Force and the Mixed Waste Working Group, reported that the FFCA task force would be meeting on May 25 and 26 in Washing,on, DC. She noted that, at the request of working group members, a presentation and discussion regarding the acceptance of commercial mixed waste at DOE sites would occur during the statesonly portion of the meeting.

In preparation for the FFCA task force meeting, working group members agreed to

- recommend to the full LLW Forum that Forum Participants contact their state representatives on the FFCA task force and urge their support in adding the issue of DOE acceptance of commercial mixed wast c for treatment and disposal to the FFCA task force discussions;

- use the May 19 mixed waste information meeting sponsored by DOE's National Low-Level Waste Management Program at EG\&G Idaho to discuss commercial mixed waste treatment and disposal issues in detail prior to the FFCA meeting;

- invite participation in the May 19 preparatory meeting from states not currently represented on the LLW Forum Mixed Waste Working Group; and

- address a letter requesting specific information to James Turi, the LLW Forum's DOE contact for the FFCA Task Force and request that the information be provided prior to the May 19 meeting (See "New Materials and Publications," this issue.)

\section{Attendance}

Attending the meeting were the following working group members:

- Elaine Carlin of the Northwest Interstate Compact on Low-Level Radioactive Waste Management;

- Ronald Gingerich of the Connecticut Hazardous Waste Management Service;

- Teresa Hay of the Midwest Interstate Low-Level Radioactive Waste Compact Commission and the lowa Department of Natural Resources;

- Kevin McCarthy of the Northeast Interstate LowLevel Radioactive Waste Commission and the Connecticut Department of Environmental Protection;

- Lee Mathews of the Texas Low-Level Radioactive Waste Authority; and

- Don Womeldorf of the Southwestern Low-Level Radioactive Waste Compact Commission.

Others in attendance included:

- Dru Butler of the Washington Department of Ecology;

- William Dornsife of the Pennsylvania Department of Environmental Resources;

- Domenic Forcella of the Connecticut Hazardous Waste Management Service;

- Joe Stohr of the Northwest Interstate Compact on Low-Level Radioactive Waste Management;

- Marijo Kerr of the National Low-Level Waste Management Program, who made a report at the invitation of the Working Group; and

- Holmes Brown, Laura Scheele, and M. A. Shaker of Afton Associates, Inc.

For further information, contact Laura Scheele, LLW Forum Mixed Waste Working Group Coordinator of Afton Associates at (202)547-2620. 


\section{Chart: U.S. EPA Office of Radiation and Indoor Air Rulemakings}

\section{Criteria and Standards Division}

IF@II I994k

\section{Low-Level Waste Standard}

(Environmental Standards for the Management and Disposal of Low-Level Waste)

NRC-Licensed Centralized

LLW Treatment/Storage Facilities

NRC-Licensed LLW Disposal Facilities

DOE LLW Treatment and Disposal Facilities 

To provide for comprehensive, consistent coverage of all Atomic Energy Act low-level radioactive waste management and disposal.

Based on EPA Staff Draft

- Sets an all-pathways individual protection limit of $15 \mathrm{mrem} / \mathrm{yr}$ for pre-disposal management and storage.

- Includes an all-pathways provision individual protection limit of $15 \mathrm{mrem} /$ year for long-term disposal site performance.

- Limits the contamination of underground sources of drinking water to the Maximum Contaminant Levels (MCLs) of 40 CFR 141 (e.g., $4 \mathrm{mrem} /$ year for beta/photon emitters).

\section{III}

Sets environmental protection standards for lowlevel radioactive waste disposal facilities. Standards would be implemented by U.S. NRC or Agreement States. 


\section{Chart: U.S. EPA Office of Radiation and Indoor Air Rulemakings}

\section{Radiation Studies Division}

IF 2111924

IIL

\section{Radiation Site Cleanup Regulation}

NRC and Agreement State Licensees

CERCLA (Superfund) sites, if regulation is adopted as an Applicable or Relevant and Appropriate Requirement (ARAR) for such sites

Federal Facilities
Fol1 IDQ5 ini

\section{Comprehensive Waste Management Rule}

$\rightarrow$ EPA and NRC have signed a Momorandum of Understanding (MOU). Under the MOU, if EPA determines that NRC's regulatory program affords a sufficient level of protection, EPA will propose in the Fedoral Register that NRC and Agroement State licensees be oxempt from EPA's rogulations.
To set health-based standards for the remediation of soil, groundwater, surface water and structures contaminated with all types of radioactive materials.

\section{Based on EPA Staff Draft}

- Anticipates three land uses: residential unrestricted use, commercial use and on-site disposal.

- Requires active control measures for commercial land use and on-site disposal.

- Limits individual dose levels to $15 \mathrm{mrem} /$ year above natural background radiation over 30 years of exposure.

- Limits the contamination of underground sources of drinking water to the Maximum Contaminant Levels (MCLs) of 40 CFR 141 (e.g., $4 \mathrm{mrem} /$ year for beta/photon emitters).

Could affect volumes of low-level radioactive waste destined for disposal.
To establish uniform standards for the treatment, storage, and disposal of waste generated during radioactive site cleanups.

Still in initial phase.

- Explores the feasibility of developing a riskbased scheme to indicate the suitability of all types of radioactive waste for various treatment, storage and disposal options. The scheme would be indeperiuent of, yet consistent with, the current statutory or regulatory classification for the wastes.

- Evaluates options for treatment, storage and disposal of all types of radiation site cleanup waste.

- Evaluates options for waste minimization and pollution prevention for all types of radiation site cleanup waste.

Could affect the types of waste allowed in lowlevel radioactive waste disposal facilities.

Could affect facility design requirements. 


\section{Federal Agencies and Committees}

Environmental Protection Agency

\section{EPA Issues Draft Radiation Site Cleanup Regulation}

The U.S. Environmental Protection Agency (EPA) has issued a preliminary draft Radiation Site Cleanup Regulation that sets standards for remediation of soil, ground water, surface water and structures at federal facility sites contaminated with radioactive material. The regulation is intended to allow these sites to be released for public use. The proposed rule will also ensure that contaminated sites that are to be released are remediated to a consistent level. According to EPA staff, this rule will not mandate the cleanup of sites.

EPA also issued an arcompanying preliminary staff working draft Notice of Proposed Rulemaking, which provides a summary of the draft regulation, the background and goals of the rulemaking, a description of the draft regulation, an analysis of EPA's statutory authority for the regulatory approach, and EPA's policy and technical rationale for the proposed regulatory approach. According to EPA, the draft Notice of Proposed Rulemaking is intended to be used primarily to maximize public discussion and comment.

\section{Overall Risk Standards}

The preliminary draft regulation, issued on May 18, calls for an annual committed effective dose limit for members of the public of 15 millirem (mrem) per year above natural background levels for 1,000 years after the completion of the cleanup.

Site remediation activities must also ensure that individual dose levels from underground sources of drinking water do not exceed the limits (maximum contaminant levels) contained in EPA's drinking water standard. These limits are intended to protect the reasonably maximally exposed individual, which is the individual receiving an exposure level in the upper five percent for individuals at the site.
If a site has not been remediated 10 allow for unrestricted residential use, the site owner or operator will be required to implement active control measures, such as limitations on land use, to ensure that human health and the environment are protected. In a case where site cleanup is coupled with active control measures, remedial action must ensure that individuals located at a released site are not exposed to radioactive materials at levels in excess of the limits for unrestricted residential land use. At sites employing active control measures as part of the remedial action to allow for release of the site, the ainnual committed effective dose limit for an individual must not exceed 75 mrem per year even in the event that all of the active control measures fail.

The preliminary draft Radiation Site Cleanup Regulation mistakenly refers to a time frame of 10,000 years after which "radionuclide concentrations in excess of natural background levels shall not exceed" the dose limits specified in the rule. An EPA staff member has confirmed that the time frame is actually 1,000 years. The draft notice of proposed rulemaking contains the correct time frame, as will revised versions of the rule.

\section{Additional Highlights}

In addition to the limits described above, the preliminary draft regulation addresses the following issues:

- If a site is not remediated to allow for unrestricted residential use, the site will be reevaluated periodically to ensure that the dose limit of 15 mrem per year is not exceeded for any member of the public and to evaluate whether further cleanup is needed.

- All existing and future structures on remediated sites must meet the guidelines of the EPA Radon Program. 


\section{Federal Agencies and Committees continued}

- EPA anticipates that future guidance will indicate "work practices" that will facilitate cleanups on a consistent basis to potentially lower individual dose limits to below 15 mrem per year.

- The rule calls for mandatory public participation requirements for site owners and operators. Public notice and comment would be required during the following phases in the cleanup process: intention to remediate, determination of preferred land use, revision to preferred land use, intention to release, failure of active control measures, and results of the periodic review.

\section{Applicability of Proposed Rule}

The Radiation Site Cleanup Regulation will apply to federal facilities, including U.S. Department of Energy (DOE) and U.S. Department of Defense (DOD) facilities. U.S. Nuclear Regulatory Commission (NRC) and Agreement State licensees are potentially subject to the Radiation Site Cleanup Regulation. However, EPA and NRC have signed memorandum of agreement on coordinating their standards and avoiding duplicate regulation. NRC has issued draft proposed residual contamination standards for site cleanup. If EPA finds the NRC rules sufficiently protective of public health, the agency will use a rulemaking process to exempt NRC licensees from the agency's Site Cleanup Regulation.

In addition, the EPA draft proposed rule could be adopted as an Applicable or Relevant and Appropriate Requirement for sites being cleaned up under the Comprehensive Environmental Response, Compensation, and Liability Act of 1980 (i.e., Superfund sites).

The draft proposed rule will not apply to the following entities:

- facilities regulated under 40 CFR 191, including facilities for the management and disposal of spent nuclear fuel, high-level and transuranic wastes;

- uranium mill tailings piles disposed of under 40 CFR 192; and

- Superfund sites with signed Records of Decision as of the effective date of the rule.

\section{Relationship to Comprehensive Radioactive Waste Management Rule}

The Comprehensive Radioactive Waste Management Rule is expected to be issued in the Fall 1995. In the draft Notice of Proposed Rulemaking for the Radiation Site Cleanup Regulation, EPA explained the relationship between the draft Radiation Site Cleanup Regulation and the Waste Management Rule. Under the Waste Management Rule, EPA is developing proposed regulations to establish uniform standards governing the management of radioactive waste materials, including those waste materials generated during radioactive site cleanups. The Waste Management Rule will set standards that provide for the protection of human health and the environment and that promote cost-effective and feasible approaches to radioactive waste management, including disposal. In the draft Notice of Proposed Rulemaking, EPA explains that the issues which the agency is currently evaluating regarding radioactive waste management include

the scope and applicability of the waste management rules and the relationship between regulatory standards and guidance to deal with waste treatment, storage, and disposal activities. The Agency is also evaluating how today's proposal will affect the volumes of waste generated during radioactive site cleanup in relation to the availability of waste disposal sites and their capacities. The Agency realizes that given the potential inadequacy of existing licensed disposal sites to accommodate the volumes of radioactive waste anticipated from site cleanups, alternative waste management options should be considered including the use of above-ground on site retrievablestorage.

The notice also states that "[ $t]$ hese and other issues currently under review by the Agency will be presented in a Radioactive Waste Management Issues Paper to be published by EPA in the near future."

(See chart, pp. 26-27 for further information.)

continued on page 30 


\section{Federal Agencies and Committees continued}

\section{Environmental Protection Agency \\ (continued)}

\section{Opportunity for Comment}

During the meeting of the Radiation Site Cleanup Regulation Subcommittee of the Environmental Information and Assessments Committee of the National Advisory Council for Environmental Policy and Technology (NACEPT), EPA announced a brief comment period for the preliminary draft regulation. All comments received will become part of the administrative record for the rule.

Comments must be received by June 10, 1994, and should be addressed to

The Docket

U.S. Environmental Protection Agency;

ATTN: Air and Radiation Docket

Mail Stop 6102

Air Docket No. A-93-27

Room M1500; First Floor Waterside Mall

401 M Street, S.W.

Washington, DC 20460.

The preceding information was distributed to Forum Panticipants/Alternates and Federal Liaisons/Altemates zia facsimile transmission in a News Flash on June 1.

The draft rule and related information are available through the Cleanup Regulation Electronic Bulletin Board at 800 700-STDS (800-700-7837) outside the Washington area and 703-790-0825 locally. Copies of the draft rule and the Notice of Proposed Rulemaking will be available from EPA's Superfund/RCRA Hotline at 800-424-9346 for calls from outside the Washington area and at 703-412-9810 for local calls.

\section{EPA Extends Mixed Waste Enforcement Moratorium}

The U.S. Environmental Protection Agency (EPA) announced in April an extension of the agency's policy on the civil enforcement of the storage prohibition of the Resource Conservation and Recovery Act (RCRA) at facilities that generate "mixed waste" regulated under both RCRA and the Atomic Energy Act. In the Federal Register notice announcing the extension, EPA states that violations of the RCRA hazardous waste storage restrictions involving relatively small volumes of mixed waste will continue to be considered "reduced priorities among EPA's potential civil enforcement actions." The extension expires on April 20, 1996, and EPA staff has indicated that the policy is not likely to be extended again.

\section{Mixed Waste and Land Disposal Restrictions}

Mixed waste contains both a hazardous waste component regulated under subtitle $\mathrm{C}$ of RCRA and a radioactive component regulated under the Atomic Energy Act. As a subset of hazardous waste, mixed wastes are subject to the land disposal restrictions contained in 40 CFR Part 268. Mixed wastes are also subject to storage prohibitions, which forbid the storage of a waste that is restricted from land disposal except "for the purpose of the accumulation of such quantities of hazardous waste as are necessary to facilitate proper recovery, treatment, or disposal."

Currently, only one facility provides disposal capacity for certain types of commercially generated mixed waste, and treatment options are limited for much of the mixed waste generated by commercial activities or by the U.S. Department of Energy (DOE). EPA previously determined that storage of a waste pending development of treatment capacity does not constitute storage to accumulate sufficient quantifies to facilitate proper treatment or disposal. However, given the lack of treatment and disposal capacity specifically for mixed waste, EPA has determined that generators may have little option but to store mixed waste until adequate capacity is obtained. 


\section{Federal Agencies and Committees continued}

\section{Treatment Capability and the FFCA}

In the Federal Register notice, EPA expresses concern over the limited improvement in mixed waste treatment capacity since enactment of the 1991 enforcement moratorium. The agency states that its "willingness to extend this Policy is predicated on indications that there may be positive developments in the treatment capacity area during the period of the two-year extension." The indications include improvements in treatment capability that are being pursued by a few facilities. EPA also references DOE's identification of mixed waste treatment needs as an indication of positive developments, since DOE's waste volumes far exceed those of the commercial sector.

Under the Federal Facility Compliance Act (FFCA), DOE, the states and EPA are required to develop and approve site-specific treatment plans for mixed waste at DOE sites by October 1995. EPA stated that it

cannot ignore the important linkage of overall mixed waste treatment capacity development to the planning process underway under the FFCA ... The option of consolidating the management of DOE and commercially generated wastes has been a tupic of much discussion between DOE and those interests responsible for developing and regulating new commercial low-level radioactive waste facilities ... EPA urges the continuation of these discussions, and the participation of the commercial generator interests in the debate.

\section{Highlights of Extended Enforcement Policy}

The policy applies only to mixed waste facilities that generate less than 1,000 cubic feet per year of wastes that are prohibited from land disposal. This amount relates only to the annual generation rate, and not to the mixed waste inventory in storage. According to the extended enforcement policy, facility owners and/or operators should undertake the following steps in order to demonstrate that they are pursuing environmentally responsible management of mixed wastes and therefore should be accorded a reduced civil enforcement priority for storage violations:

- Records identifying the physical location of and storage method for mixed wastes should be maintained.

- Periodic compliance assessments of mixed waste storage areas should be conducted.

- Sufficient information for identification of mixed wastes in storage should be maintained.

- Waste minimization plans and implementation schedules should be developed.

- Good-faith efforts to obtain treatment capacity should be demonstrated.

Forfurtherinformation, see "New Materials and Publications."

\section{Department of Energy}

\section{Lash Named Director, DOE Office of Nuclear Energy}

President Clinton announced in May the appointment of Terry Lash as Director of the Office of Nuclear Energy in the U.S. Department of Energy (DOE). As Director, Lash will be responsible for managing the research and development programs in nuclear energy, where DOE is concentrating on advancing the safety and economy of light water reactor technology. Prior to his appointment, Lash had been serving as a Special Assistant to DOE Secretary Hazel O'Leary.
Lash is the former Director of the Illinois Department of Nuclear Safety. He also held the position of Science Director for the Scientists' Institute for Public Information. Lash was a Participant in the LLW Forum representing the state of Illinois from March 1988 to May 1990. 


\section{Federal Agencies and Committees continued}

Nuclear Regulatory Commission

\section{NRC Denies Petition to Amend Low-Level Radioactive Waste Classification Regulations}

In April, the U.S. Nuclear Regulatory Commission (NRC) denied a petition for rulemaking submitted in 1992 by the New England Coalition on Nuclear Pollution, Inc. The petition requested the amendment of NRC's regulations on classification of low-level radioactive waste in order to restrict the number and types of waste streams that can be disposed of in nearsurface disposal facilities. According to the coalition, a supplemental Environmental Impact Statement (EIS) should be prepared to address significant new information that unavailable at the time the original EIS for the 1983 low-level radioactive waste regulations was prepared. In denying the petition, the NRC stated that "the 'new information' as presented by the petitioner is not sufficient to invalidate the existing classification system or justify that $\mathrm{NRC}$ prepare the supplemental EIS."

\section{"Significant New Information"}

The coalition argued that the amendments are necessary because significant new information concerning intrusion into low-level radioactive waste disposal facilities was not available at the time the original Environmental Impact Statement (EIS) was developed. The petition asserted that three changes have occurred since the low-level radioactive waste classification contained in 10 CFR Part 61 was promulgated and that a supplemental EIS should be prepared to address the changes. NRC responded to each of the three ostensible changes and provided additional reasons for denying the petition.

\section{Changes Listed in Petition and NRC Responses}

Inadvertent Intruder Dose Limitation The coalition noted that the original EIS was based on a 500 millirem (mrem) per year dose to inadvertent intruders. International organizations, such as the International Committee on Radiological Protection and the National Council on Radiation Protection and Measurements, have issued revised guidance reducing dose limits for individual members of the public 10100 mrem peryear, and this new limit has been incorporated into 10 CFR Part 20. The petition claimed that the intruder and public dose limits are closely linked and asserted that the 100-mrem dose limit should be used in the intruder analysis. Because the waste classification system is based on the intruder analysis, this would impact the waste streams permitted to be disposed of in low-level radioactive waste facilities.

The NRC staff believed that the petition incorrectly asserted that recommendations of international organizations on public dose limits applicable to licensee operations should also be applied to hypothetical inadvertent intrusions at closed low-level radioactive waste facilities. The NRC differentiates between the 10 CFR Part 20 limit of 100 mrem-which is intended to impose restrictions upon the release from currently operating licensed facilities and from current licensee operations-and the low-level radioactive waste classification system, which is designed to address conservative assumptions regarding a hypothetical inadvertent intruder scenario evaluated in the EIS. The International Committee on Radiological Protection, in proposing that the probability and the consequences of hypothetical events like inadvertent intrusion be considered, noted that the "initial focus in controlling the consequences of potential or postulated events should be 'prevention,' that is, by incorporating provisions to reduce the probability of the postulated events which may lead to radiation exposures." The 


\section{Federal Agencies and Committees continued}

NRC staff found that the existence of multiple controls in the final low-level radioactive waste rule to reduce the likelihood of exposures to inadvertent intruders is, and continues to be, wholly consistent with the International Committee on Radiological Protection's approach.

Intrusion Scenarios The New England Coalition on Nuclear Pollution stated that the three intrusion scenarios considered in the development of 10 CFR Part 61 did not encompass a broad enough range of possibilities. According to the petition, the NRC used regulatory discretion rather than scientific data to exclude deliberate intrusion from consideration. The petition stated that studies conducted at the behest of the state of Vermont show that the ability of nearsurface facilities to properly provide isolation for all of the currently classified low-level radioactive waste streams is questionable under a deliberate intrusion scenario.

The NRC responded that protecting against deliberate intrusion would be unnecessarily conservative and unwarranted. The current regulations include provisions against intrusion by requiring government ownership of the land, maintenance of records, and the use of markers with hazard information. During development of 10 CFR Part 61, the NRC stated that "it would appear to be difficult to establish regulations designed to protect a future individual who recognizes a hazard but then chooses to ignore the hazard." The NRC staff believes that the likelihood of deliberate intrusion is very small.

Cost Estimates The coalition asserted that the cost differential between shallow-land burial facilities, assumed in the EIS, and a geologic repository of the type used for high-level waste has significantly changed since promulgation of the rule, because most currently planned low-level radioactive waste disposal facilities are using an engineered structure to isolate the waste. The petition stated that because cost considerations were a factor in the development of the waste classification system, a supplemental EIS is needed.
The NRC responded that the request for a supplemental EIS was denied for three reasons:

- first, a range of different disposal options and costs, including the use of engineered barriers and structures, was considered during the development of 10 CFR Part 61 ;

- second, although disposal costs for low-level radioactive waste disposal facilities have increased, so have the costs for other methods of waste disposal, including geologic disposal; and

- third, much of the increased cost for waste disposal facilities is independent of the technology used and attributable more to increased costs for site characterization, licensing, public involvement, and administration.

\section{Additional Rationale}

The NRC found that the perceived benefits of imposing a classification system as indicated in the petition would be exceedingly small and that such a system may result in several significant negative impacts, including the following:

- It would take years 10 revise the classification regulations. During this time, current efforts by states and compact organizations to develop facilities could be severely affected, since they would not know what waste would be acceptable in a low-level radioactive waste facility.

- If a new classification system were developed that resulted in some currently acceptable waste being unacceptable for a low-level radioactive waste facility, either congressional action would be needed to change the Low-level Radioactive Waste Policy Amendments Act of 1983 or the states would be forced to develop al ternative methods to dispose of this new class of waste.

- Additional operational exposures could be expected to occur as specific waste would need to be segregated, handled, treated, stored and transported while awaiting alternative disposal facilities. 


\section{New Materials and Publications}

\section{Document Distribution Key}

P LLW Forum Participants

A LLW Forum Alternates

F LLW Forum Federal Liaisons

ᄂ. LLW Forum Federal Alternates

T LLW Forum Media Contacts

v LLW Forum Press Monitors
1) LLW Forum Document Recipients

NLW Notes Recipients

M LLW Forum Meeting Report Recipients

\section{LLW Forum}

DM Meeting Report. Afton

Associates, Inc. May 1994.

Proceedings of the LLW Forum spring meeting, April 25-27, 1994. (Distributed on May 27, 1994.)

Getting a Handle on Volume and Curies: Potential Factors in LongRange Projections. Afton Associates, Inc. May 1994. Excerpt from the LLW Forum spring 1994 meeting report. To obtain a copy, contact Cynthia Norris of Afton Associate., Inc. at (202) 547-2620.

NAFTA and Compact Authority. Afton Associates, Inc. May 1994 Excerpt from the LLW Forum spring 1994 meeting report. To obtain a copy, contact Cynthia Norris of Afton Associates, Inc. at (202) 547-2620.

\section{LLW Forum Contact}

Infornation. Afton Associates, Inc. May 1994. (Distributed on May 27, 1994.)
P Letter from Jill Lytle, Deputy Assistant Secretary for Waste Management and Environmental Management, L.S. Department of Energy, to Gregg Larson, Convenor, LLW Forum, responding to May 9 letter to Secretary O'Leary. May 20, 1994. (Distributed on May 27, 1994.)

p Letter from Gregg Larson, Convenor, LLW Forum, to Ivan Selin, Chair, U.S. Nuclear Regulatory Commission, transmitting a resolution passed by the LLW Forum at its April 1994 meeting. The resolution concerns compact authority over the importation of waste generated outside of the United States. May 18, 1994. (Distributed on May 27,1994 .)

P Letter from Gregg Larson, Convenor, LLW' Forum, to Dan Reicher, Deputy Chief of Staff, U.S. Department of Energy, thanking Reicher for agreeing to meet with state and compact representatives this summer during the LLW Forum's meeting on July 20-July 22 in Seattle, Washington. May 16, 1994. (Distributed on May 27, 1994.)
P Letter from Gregg Larson, Convenor, LLW Forum, to Hazel O'Leary, Secretary, U.S. Department of Energy, transmitting a resolution passed by the LLW Forum at its April 1994 meeting. The resolution concerns the proposed use of commercial low-level radioactive waste disposal facilities for the disposal of DOE waste and the privatization of activities formerly conducted by DOE with the potential shifting of waste disposal responsibilities to the states and compacts. May 9, 1994. (Distributed on May 27, 1994.)

p Letter from Gregg Larson,
Convenor, LLW Forum, to
Governor Howard Dean (D-VT)
transmitting a congratulatory
resolution passed by the LLW
Forum at its April 1994 meeting.
The resolution concerns the
recently created Texas Low-Level
Radioactive Waste Disposal
Compact, of which Vermont is a
member. May 4, 1994.
(Distributed on May 27, 1994.)




\section{New Materials and Publications continued}

P Letter from Gregg Larson, Convenor, LLW Forum, to Governor Ann Richards (D-TX) transmitting a congratulatory resolution passed by the LLW Forum at its April 1994 meeting. The resolution concerns the recently created Texas Low-Level Radioactive Waste Disposal Compact, of which Texas is the host state. May 4, 1994. (Distributed on May 27, 1994.)

P Letter from Gregg Larson, Convenor, LLW Forum, to Governor John McKernan, Jr. (R$\mathrm{ME}$ ) transmitting a congratulatory resolution passed by the LLW Forum at its April 1994 meeting. The resolution concerns the recently created Texas Low-Level Radioactive Waste Disposal Compact, of which Maine is a member. May 4, 1994.

(Distributed on May 27, 1994.)

\section{States and Compacts}

\section{Central Compact/Nebraska}

PAFL Letter from Governor E. Benjamin Nelson (D-NE) to Bruce Babbitt, Secretary, U.S. Department of Interior, commending Babbitt on his decision to have earth science issues concerning the planned low-level radioactive waste disposal facility in Ward Valley, California, reviewed by the National Academy of Sciences before federal land is transferred to the state of California. The letter also suggests that the review be broadened to include "siting problems faced by other states." May 16, 1994.

(Distributed on May 27, 1994.)

\section{Northwest Compact/ \\ Washington}

PA Clarification Supplement to Northwest Interstate Compact

Resolution and Order of

December 18, 1991 as Amended by Order of May 28, 1992. Northwest Interstate Compaci on Low-Level Radioactive Waste Management. May 2, 1994. Clarification regards Envirocare. (Transmitted via facsimile on May 16, 1994, with a cover memo from Cynthia Norris of Afton Associates, Inc.)

\section{Southeast Compact/North Carolina/South Carolina}

"The Rise and Fall and Rise and Fall of American Public Policy on Disposal of Low-Level Radioactive Waste." William Newberry, Senior Program/Project Engineer, National Low-Level Waste Management Program. Winter 1993. Article appeared in the Winter 1993 edition of the South Carolina Enzironmental Law Joumal, published by the Environmental Law Society of the University of South Carolina School of Law.

\section{Southwestern Compact/ California}

PAFL Letter from Ivan Selin, Chair, U.S. Nuclear Regulatory Commission, to U.S.

Representative Robert Matsui (DCA) responding to a May 2 letter regarding the potential use of the Rancho Seco Nuclear Generating Station site to store low-level radioactive waste. May 18, 1994.
PAFL Letter from Senator ]. Bennett Johnston (D-LA), Chair, L.S. Senate Committee on Energy Resources, to Bruce Babbitt, Secretary, L.S. Department of Interior, expressing concern over delays in transferring federal land in Ward Valley, California, to the state for use in siting a low-level radioactive waste disposal facility. Due to such delays, Johnston is preparing legislation to compel conveyance of the land. A copy of the draft legislation is attached. May 16, 1994. (Transmitted via facsimile on May 24, 1994, with a cover memo from Todd Lovinger of Afton Associates, Inc.)

PafL Memorandum from Todd Lovinger, Afton Associates, Inc., to LLW' Forum Participants and Alternates, Federal Liaisons and Alternates re California court decisions in Ward Valley lawsuits: City of Needles \%. California Department of Health Services and Fort Mojave Indian Tribe v. Department of Health Services. (Transmitted via facsimile on May 6, 1994.)

TV "Judge stalls plans for nuclear waste dump." Associated Press. May.4, 1994. (Transmitted via facsimile on May 6, 1994, with a cover memo from Todd Lovinger of Afton Associates, Inc.) 


\section{New Materials and Publications continued}

\section{Document Distribution Key}

P LLW Forum Participants

A LLW Forum Alternates

F LLW Forum Federal Liaisons

L LLW Forum Federal Alternates

T LLW Forum Media Contacts

$v$ LLW Forum Press Monitors
D LLW Forum Document Recipients

N LLW Notes Recipients

M LLW' Forum Meeting Report Recipients
Items transmitted via facsimile $r e$ the transfer of federal land to the state of California for the planned low-level radioactive waste disposal facility in Ward Valley, California. Transmitted on May 10 1994, with a cover memo from Todd Lovinger of Afton Associates, Inc.

PAFLTV Lett $r$ from Brure Babbitt, Secretary, U.S. Department of Interior, to Senator J. Bennett Johnston (D-LA), Chair, U.S. Senate Committee on Energy Resources, responding to a March 23 letter from Johnston that expressed concern over the delay in transferring federal land to he state of California for the planned disposal facility. May 4, 1994.

PAFLTV Letter from Bruce Babbitt, Secretary, U.S. Department of Interior, to Senator Barbara Boxer (D-CA) responding to an earlier letter from Boxer concerning the facility. May 4, 1994.

PAFL Letter from Don Womeldorf, Executive Director, Southwestern Low-Level Radioactive Waste Compact Commission, to Jan Schori, General Manager, Sacramento Municipal Utility
District, re recent activities of the utility district to consider storage of low-level radioactive waste at the closed Rancho Seco nuclear power plant. May 3, 1994. (Transmitted via facsimile on May 4, 1994, with a cover memo from Cynthia Norris of Afton Associates, Inc.)

PAFL Letter from U.S.

Representative Robert Matsui (DCA), to Ivan Selin, Chair, L'S. Nuclear Regulatory Commission, concerning a proposal to store low-level radioactive waste at the closed Rancho Seco nuclear power plant near Sacramento, California. May 2, 1994. (Transmitted via facsimile on May 19, 1994, with a cover memo from Todd Lovinger of Afton Associates, Inc.)

PAFL Letter from U.S.

Representative John Dingell (DMI), Chair, House Committee on Energy and Commerce, to President Bill Clinton re the planned low-level radioactive waste disposal facility in Ward Valley, California. May 2, 1994.

(Transmitted via facsimile on May 13,1994 , with a cover memo from Todd Lovinger of Afton Associates, Inc.)
Items transmitted via facsimile re the planned low-level radioactive waste disposal facility in Ward Valley, California. Transmitted on May 2, 1994, with a cover memo from Cynthia Norris of Afton Associates, Inc.

PAFL Letter from Governor Pete Wilson (R-CA) to Senator Barbara Boxer (D-CA), responding to Boxer's request for revocation of the license for the disposal facility. April 27, 1994.

PAFL Letter from President Bill Clinton to Dana Mount, Chair, Southwestern Low-Level Radioactive Waste Compact Commission, re the transfer of federal land to the state of California for the facility. April 12, 1994. 


\section{New Materials and Publications continued}

\section{Document Distribution Key}

\author{
LLW Forum Participants \\ LLW Forum Alternates \\ LLW Forum Federal Liaisons \\ LLW Forum Federal Alternates \\ LLW Forum Media Contacts \\ LLW' Forum Press Monitors
}

D LLW Forum Document Recipients

N LLW Notes Recipients

M LLW Forum Meeting Report Recipients
Integrated Data Base for 1993: LI.S. Spent Fuel and Radioactive W'aste Inventories, Projections, and Characteristics (DOE/RW-0006, Rev. Y). Prepared for the U.S. Department of Energy, Office of Civilian Radioactive Waste Management, Office of Environmental Restoration and Waste Management, by Oak Ridge National Laboratory. March 1994. Summarizes DOE's data base for inventories, projections, and characteristics of domestic spent nuclear fuel and radioactive waste. To obtain a copy, contact the Office or Scientific and Technical Information at (615)576-8401.

Technical Bulletin: Lou-Lezel. Radioactive. Waste Disposal Technologies Used Outside of the United States (EGG-LLW-11026-94 1). Prepared for the National Low-Level Waste Management Program by Kelli Templeton, Sue Mitchell, Peter Molton, and Inga Leigh. January 1994. Outlines the low-level radioactive waste disposal technologies that are planned or being used in Canada, China, Finland, France, Germany, Japan, Sweden, Taiwan and the United Kingdom. To obtain a copy, contact Donna Lake of EG\&G Idaho at (208) 526-6927.

\section{Environmental Protection Agency}

"Extension of the Policy on Enforcement of RCRA Section 3004(J) Storage Prohibition at Facilities Generating Mixed Radioactive/Hazardous Waste." 59 Federal Register 18813. L'.S. Environmental Protection Agency. April 20, 1994. Forum Participants and Alternates, Federal Liaisons and Alternates may obtain a copy by contacing Laura Scheele of Afton Associates. Inc. at (202) 547-2620.

Executive Order 12898: Federal Actions to Address Environmental Justice in Minority Populations है Low-Income Populations. Greg Mertz, U.S. Environmental Protection Agency. Hard copies of slides. April 1994. Forum Participants and Alternates, Federal Liaisons and Alternates may obtain a copy by contacting Laura Scheele of Afton Associates, Inc. at (202) 547-2620.
EPA Research Series: Radiation and Mixed Waste Incineration (ISBN: 0 86587-386-0). Government Institutes, Inc. February 1994. This EPA background document contains two volumes on technology and the risk of radiation exposure. The first volume provides technical guidance on radioactive and mixed waste (low-level radioactive contaminated waste) incineration. The second volume describes the major public health issues and current regulatory structures associated with radioactive materials. To obtain a copy, contact Government Institutes, Inc. at (301)921-2355. (The document can be obtained with a major credit card at the cost of $\$ 85$. Please use the title and \#386 to expedite your order.)

\section{General Accounting Office}

Nuclear Waste: Much Effort Needed to Meet Federal Facility Compliance Act's Requirements (GAO/RCED-94179). U.S. General Accounting Office. May 1994. A report to congressional committees concerning DOE's handling of mixed waste under the Federal Facility Compliance Act (FFCA). To obtain a copy, contact GAO at (202)512-6000. 


\section{New Materials and Publications continued}

PAFL Letter from Sherry Meddick, Nuclear/Radioacuve Waste Campaign, Greenpeace, to Ron Joseph, Chief Deputy Director for Operations, California

Department of Health Services, requesting information on the state's financial arrangements with the Southwestern Low-Level Radioactive Waste Compact Commission and for a detailed accounting of commission funding. April 28, 1994. (Transmitted via facsimile on May 16, 1994, with a cover memo from Cynthia Norris of Afton Associates, Inc.)

\section{Massachusetts}

1993 Annual Report to the Commonwealth: December 1, 1992-

November 30, 1993. Massachusets Low-Level Radioactive Waste Management Board. March 1994. To obtain a copy, contact Ben McKelway of the Massachusetts Board at (617)727-6018. (Please limit your request to one copy due. to a limited budget.)

\section{Vermont}

PAFL Press release re Vermont's enactment of legislation to join the Texas Low-Level Radioactive Waste Disposal Compact. State of Vermont, Office of the Governor. April 21, 1994. (Transmitted via facsimile on April 26, 1994, with a cover memo from Cynthia Norris of Afton Associates, Inc.)

\section{Federal Agencies}

\section{Department of Energy}

Items transmitted via facsimile re the proposed use of commercial low-level radioactive waste disposal facilities for the disposal of DOE waste and the privatization of activities formerly conducted by DOE with the potential shifting of waste disposal responsibilities to the states and compacts.

Transmitted on May 12 1994, with a cover memo from Todd Lovinger of Afton Associates, Inc.

Tv Letter from Gregg Larson, Convenor, LLW Forum, to Hazel O'Leary, Secretary, U.S. Department of Energy, transmitting a resolution passed by the LLW Forum at its April 1994 meeting. The resolution concerns the proposed use of commercial low-level radioactive waste disposal facilities for the disposal of DOE waste and the privatization of activities formerly conducted by DOE with the potential shifting of waste disposal responsibilities to the states and compacts.

May 9, 1994.

Tv "Ohio, L.S. at odds over plant's nuclear waste." Cleveland Plain Dealer. May 12, 1994.
National Lout-Lerel Waste Management Program Radionuclide Repont Series, Volume 6: Cesium-137 (DOE/LLW-122). National LowLevel Waste Management Program. May 1994. Discusses radiological and chemical characteristics of cesium 137. This report also includes discussions about waste streams in whi cesium 137 can be found, waste forms that contain cesium 137, and the behavior of cesium 137 in the environment and in the human body. To obtain a copy, contact Donna Lake of EG\&G Idaho at (208)526-6927.

PA Letter from Dan Reicher, Deputy Chief of Staff, U.S. Department of Energy, to Gregg Larson, Convenor, LLW Forum, responding to discussion items raised during a March 21 meeting with the LLW Forum Executive Commiuee. April 26, 1994. (Transmitted via facsimile on April 27, 1994, with a cover memo from Laura Scheele of Afton Associates, Inc.)

FRMAC-93 Lessons Learmed Report (DOE/NV-367). Prepared by EG\&G Energy Measurements for U.S. Department of Energy, Nevada Operations Office. March 1994. Describes a major 2day field exercise designed to determine the effectiveness, coordination, and operations of a DOE-managed Federal Radiological Monitoring and Assessment Center. To obtain a copy, contact the National Technical Information Service at (703) 487-4600. 


\section{New Materials and Publications continued}

\section{Nuclear Regulatory Commission}

- PA "Procedures and Criteria for On-Site Storage of Low-Level Radioactive Waste." 59 Federal Register 19147. Proposed rule; withdrawal. U.S. Nuclear Regulatory Commission. April 22, 1994. (Transmitted via facsimile on May 4, 1994, with a cover memo from Laura Scheele of Afton Associates, Inc.)

Memorandum from Richard Bangert, Director, Office of State Programs, U.S. Nuclear Regulatory Commission, to State Liaison Officers and all Agreement and Non-Agreement States, re denial of petition for rulemaking from the New England Coalition on Nuclear Pollution, Inc. April 21, 1994.
"New England Coalition on

Nuclear Pollution, Inc.; Denial of

Petition for Rulemaking." 59

Federal Register 17052. U.S. Nuclear Regulatory Commission.

April 11, 1994.

Standard Review Plan for the Reriew of a License Application for a Lou'Level Radioactive Waste Disposal Facility (NUREG-1200). U.S. Nuclear Regulatory Commission, Office of Nuclear Material Safety and Safeguards. April 1994.

Provides guidance to staff reviewers in the Office of Nuclear Material Safery and Safeguards who perform safety reviews of applications to construct and operate low-level radioacuive waste disposal facilities. To obtain a copy, contact the National Technical Information Service at (703) 487-4600.

\section{Other}

PATV "Comments to U.S.

Representatives, Senators and staff members on the Implementation of the Low-Level Radioactive Waste Policy Act and Amendments Act." Nuclear Information and Resource Service. March 22, 1994. Press release. (Transmitted via facsimile on April 21, 1994, with a cover memo from Todd Lovinger of Afton Associates, Inc.)

God's Earth Our Home.

Environmental and Economic Justice/Hunger Concerns Working Group of the National Council of Churches of Christ in the USA. March 1994. An educational resource for study and action on environmental and economic justice in the United States. To obtain a copy call (800)441-3712.

\section{Receiving $L L W$ Notes by Mail}

LLW Notes and the Summary Report: Lou-Level Radioactive Waste Management Activities in the States and Compacts is distributed to state, compact and federal officials designated by LLW Forum Participants and Federal Liaisons. In April 1994, Forum Participants unanimously approved a change in LLW Forum procedures in order to allow representatives of industry, environmental and citizen groups-as well as other interest groups and members of the public - to receive these two publications directly by mail.

Members of the public may now apply to the National Low-Level Waste Program at EG\&G Idaho to be placed on a public information mailing list for copies of $L L W$ Notes and the supplemental Summary Report. Afton Associates, the LLW Forum's management firm, will provide copies of these publications to EG\&G. The LLW Forum will monitor distribution of these documents to the general public to ensure that information is equitably distributed throughout the states and compacts. This system of distribution is being established on a trial basis and will be reviewed before the end of 1994 to determine whether it meets the needs of citizens and is affordable to the LLW Forum.

For further information on receiving LLW Notes and the Summary Repont by mail, please contact Donna Lake, Senior Administrative Specialist, EGEG Idaho, Inc., at (208)526-0234. 




The Low-Level Radioactive Waste Forum includes a Participant from each regional compact, current host state, future host state and unaffiliated state. Graphic by Afton Associates, Inc. for the LLW Forrem. May 1994. 